\title{
Mechanistic Studies of Methanol Oxidation to Formaldehyde on Isolated Vanadate Sites Supported on High Surface Area Anatase
}

\author{
Jason L. Bronkema, Dewi C. Leo, and Alexis T. Bell* \\ Chemical Sciences Division, Lawrence Berkeley National Laboratory, and Department of Chemical \\ Engineering, University of California, Berkeley, California 94720-1462 \\ Received: May 17, 2007; In Final Form: July 17, 2007
}

\begin{abstract}
The mechanism for methanol oxidation on both $\mathrm{TiO}_{2}$ and $\mathrm{V} / \mathrm{TiO}_{2}$ was investigated using temperatureprogrammed experiments with in-situ infrared spectroscopy. Infrared and Raman spectroscopy, along with XANES, show that the $\mathrm{V} / \mathrm{TiO}_{2}$ sample consists predominantly of isolated $\mathrm{VO}_{4}$ units after calcination. Methanol was found to adsorb on the catalyst in three ways at $323 \mathrm{~K}$ : (1) molecularly, (2) across $\mathrm{Ti}-\mathrm{O}-\mathrm{Ti}$ bonds to form $\mathrm{Ti}-\mathrm{OCH}_{3} / \mathrm{Ti}-\mathrm{OH}$ pairs, and (3) across $\mathrm{V}-\mathrm{O}-\mathrm{Ti}$ bonds to form $\mathrm{V}-\mathrm{OCH}_{3} / \mathrm{Ti}-\mathrm{OH}$ pairs. Upon heating, two desorption peaks for $\mathrm{CH}_{3} \mathrm{OH}$ and $\mathrm{H}_{2} \mathrm{O}$ were observed on all samples below $500 \mathrm{~K}$. Although $\mathrm{TiO}_{2}$ produced small amounts of $\mathrm{CH}_{2} \mathrm{O}$, the addition of vanadium greatly enhanced the rate of formaldehyde formation. Also, on the $\mathrm{V} / \mathrm{TiO}_{2}$ samples, it was noticed that the $\mathrm{Ti}-\mathrm{OCH}_{3}$ groups disappear much more rapidly than on $\mathrm{TiO}_{2}$ alone. This is likely due to the reverse spillover of methoxide species from $\mathrm{Ti}$ to $\mathrm{V}$, with the reaction occurring at lower temperatures at the vanadium center. Formate species were also detected during the experiments, and they are assumed to be intermediates in the decomposition of formaldehyde to $\mathrm{CO}, \mathrm{CO}_{2}$, and $\mathrm{H}_{2} \mathrm{O}$. The apparent activation energy of $\mathrm{V} / \mathrm{TiO}_{2}$ for the formation of $\mathrm{CH}_{2} \mathrm{O}$ is $16 \mathrm{kcal} / \mathrm{mol}$.
\end{abstract}

\section{Introduction}

Isolated vanadate groups supported on metal oxides such as $\mathrm{SiO}_{2}, \mathrm{Al}_{2} \mathrm{O}_{3}, \mathrm{ZrO}_{2}$, and $\mathrm{TiO}_{2}$ have been shown to be active for the selective oxidation of methanol to formaldehyde. ${ }^{1-3}$ Characterization of the vanadate centers by multiple techniques has demonstrated that at low vanadium coverages the supported $\mathrm{VO}_{4}$ species have a distorted tetrahedral geometry containing a single $\mathrm{V}=\mathrm{O}$ bond and three $\mathrm{V}-\mathrm{O}-\mathrm{M}$ bonds $(\mathrm{M}=$ support metal $)$, irrespective of support composition. ${ }^{4-7}$ The composition of the support, however, has a large effect on catalyst activity. For example, it has been reported that the activity of $\mathrm{VO}_{x} / \mathrm{TiO}_{2}$ is 3 orders of magnitude higher than that of $\mathrm{VO}_{x} / \mathrm{SiO}_{2}$ under comparable reaction conditions. ${ }^{1}$ The cause for this remarkable sensitivity to support composition is not well understood and, in particular, why $\mathrm{TiO}_{2}$ should increase the activity for formaldehyde formation by such a large degree. In this connection, it has been reported that the activation energies for the oxidation of methanol to formaldehyde occurring on titaniaand silica-supported vanadia are similar, suggesting that support composition affects the preexponential factor in some manner. ${ }^{1}$

Attempts to understand the interactions of methanol with $\mathrm{TiO}_{2}$ and $\mathrm{VO}_{x} / \mathrm{TiO}_{2}$ have been reported by several investigators. For example, studies of methanol adsorption on both anatase powder and titania single crystals by Barteau and co-workers have shown that methanol can adsorb both molecularly and dissociatively. ${ }^{8,9}$ In the latter case, methanol reacts with $\mathrm{Ti}-\mathrm{O}-\mathrm{Ti}$ bonds to form $\mathrm{Ti}-\mathrm{OCH}_{3} / \mathrm{Ti}-\mathrm{OH}$ pairs. During temperatureprogrammed desorption (TPD), methanol and water desorb from the catalyst at temperatures below $600 \mathrm{~K}$ due to the recombination of $\mathrm{Ti}-\mathrm{OCH}_{3} / \mathrm{Ti}-\mathrm{OH}$ and $\mathrm{Ti}-\mathrm{OH} / \mathrm{Ti}-\mathrm{OH}$ pairs, respectively. At temperatures above $600 \mathrm{~K}$, small amounts of formaldehyde, dimethylether, methane, carbon monoxide, and carbon dioxide are produced via a variety of reactions involving

* Corresponding author. E-mail: alexbell@berkeley.edu.
$\mathrm{Ti}-\mathrm{OCH}_{3}$ species. Henderson and co-workers and Vohs and co-workers have conducted similar studies on single-crystal $\mathrm{TiO}_{2}(110)$ surfaces. ${ }^{10,11}$ Both groups found that only methanol desorbed into the gas phase during temperature-programmed desorption (TPD); however, Henderson and co-workers did observe the formation of small amounts of formaldehyde when the $\mathrm{TiO}_{2}(110)$ surface was first dosed with $\mathrm{O}_{2}$. Vohs and coworkers also examined the interactions of methanol with vanadia dispersed on a $\mathrm{TiO}_{2}(110)$ surface. In this case, a small amount of formaldehyde was observed in addition to desorption of methanol. Similar studies have been conducted more recently by Wang and Madix. ${ }^{12}$ These authors observed the desorption of methanol at $410 \mathrm{~K}$ and the formation of a very small amount of formaldehyde at $650 \mathrm{~K}$ following methanol absorption onto a $\mathrm{TiO}_{2}(110)$ surface. Predosing the surface with oxygen prior to the adsorption of methanol resulted in the formation of a second methanol peak at $650 \mathrm{~K}$ and a significant enhancement in the production of formaldehyde. The addition of submonolayer quantities of vanadia onto the titania surface led to a decrease in the amount of methanol adsorbed and to a shift in the peak temperature for formaldehyde formation to lower values.

The objective of this study was to investigate the mechanism of methanol oxidation to formaldehyde catalyzed by isolated vanadate species supported on titania. Raman spectroscopy, infrared spectroscopy, and XANES were used to characterize the catalyst, and in-situ infrared spectra acquired during temperature-programmed desorption (TPD), temperature-programmed oxidation (TPO), and temperature-programmed reaction (TPRx) were used to determine reaction intermediates leading to the formation of formaldehyde as well as other products observed in the gas phase. These studies show that while titania will adsorb methanol and promote its oxidation to formaldehyde, the introduction of isolated vanadate species onto the support greatly enhances the rate of formaldehyde formation. 
It is also found that the presence of vanadate groups on the surface of titania enhances the reactivity of $\mathrm{Ti}-\mathrm{OCH}_{3}$ groups relative to what is observed in the absence of vanadia.

\section{Experimental Methods}

Vanadium oxide was deposited onto anatase (Aldrich, 99.7\%) by chemical vapor deposition. Vanadium acetylacetonate [VO$(\mathrm{acac})_{2}$ ] (Aldrich, 98\%) and $\mathrm{TiO}_{2}$ were mixed in a mortar and pestle and then placed inside a quartz reactor. The mixture was heated to $513 \mathrm{~K}$ at $5 \mathrm{~K} \mathrm{~min}^{-1}$ in $\mathrm{N}_{2}$ flowing at $30 \mathrm{~cm}^{3} \mathrm{~min}^{-1}$ and then held at this temperature for $3 \mathrm{~h}$ to ensure complete reaction. The gas flow was changed to zero-grade air flowing at $100 \mathrm{~cm}^{3} \mathrm{~min}^{-1}$, and the material was calcined at $773 \mathrm{~K}$ for $17 \mathrm{~h}$. The loading of $\mathrm{V}$ was determined to be $1.6 \mathrm{wt} \%$ by ICP.

The BET surface area of the sample was measured using an Autosorb-1 instrument. Prior to carrying out $\mathrm{N}_{2}$ adsorption/ desorption measurements, each sample $(50 \mathrm{mg})$ was outgassed for $16 \mathrm{~h}$ at $393 \mathrm{~K}$. Using the five-point BET method, the surface area was calculated to be $97 \mathrm{~m}^{2} / \mathrm{g}$. Based on this surface area, the surface density of vanadium is $2.0 \mathrm{~V} / \mathrm{nm}^{2}$, which is well below the level of $7 \mathrm{~V} / \mathrm{nm}^{2}$ at which isolated vanadate groups begin to form polyvanadate species and $\mathrm{V}_{2} \mathrm{O}_{5}$ crystallites. ${ }^{13}$

Raman spectra were recorded using a Kaiser Optical HoloLab series 5000 Raman spectrometer equipped with a Nd:YAG laser that is frequency-doubled to $532 \mathrm{~nm}$. The laser was operated at a power level of $20 \mathrm{~mW}$ measured at the sample with a power meter. A Princeton Instruments TEA/CCD detector was operated at $-40{ }^{\circ} \mathrm{C}$. Spectra were recorded with a resolution of $2 \mathrm{~cm}^{-1}$. Samples (approximately $25 \mathrm{mg}$ each) were pressed into pellets at $5000 \mathrm{psi}$ and placed within a rotary quartz Raman cell. The samples were rotated at $100 \mathrm{rpm}$ during the measurements to reduce the effects of sample heating by the laser.

Infrared spectra were recorded using a Thermo-Nicolet NEXUS 670 FT-IR equipped with an MCT-A detector. Spectra were recorded with a resolution of $2 \mathrm{~cm}^{-1}$, with 32 scans averaged for each spectrum. Samples $(40 \mathrm{mg})$ were pressed into $20 \mathrm{~cm}$ diameter pellets at 10000 psi and placed within a low dead volume in-situ infrared cell, containing $\mathrm{CaF}_{2}$ windows, capable of reaching temperatures up to $773 \mathrm{~K}$.

Pulsed-adsorption of methanol was performed to determine the amount of methanol adsorbed on $\mathrm{TiO}_{2}$ and $\mathrm{V} / \mathrm{TiO}_{2}$. For these experiments, $\sim 40 \mathrm{mg}$ of catalyst was placed into a quartz microreactor. The reactor was flushed with UHP He and then heated to $323 \mathrm{~K}$. Methanol was introduced by flowing UHP He through a methanol-filled bubbler maintained at $293 \mathrm{~K}$. The methanol/He mixture was passed through a six-way valve to which was attached a $0.49 \mathrm{~cm}^{3}$ dosing volume held at $338 \mathrm{~K}$. Under these conditions, the amount of methanol in each pulse was $2.28 \mu \mathrm{mol}$. The exit stream from the microreactor was monitored by a mass spectrometer to quantify the methanol leaving the reactor during each pulse. Pulses of methanol were supplied to the reactor until three successive pulses of equal size were observed. The total amount of methanol adsorbed, $N_{\mathrm{MeOH}}$, was calculated by the equation:

$$
N_{\mathrm{MeOH}}=N_{\mathrm{MeOH}}^{0}\left(n A_{\max }-\sum_{i=1}^{n} A_{i}\right) / n A_{\max }
$$

where $N_{\mathrm{MeOH}}^{0}$ is the amount of methanol in each pulse, $n$ is the total number of pulses, $A_{\max }$ is the average area of the three successive pulses measured at the point of adsorbent saturation, and $A_{i}$ is the area of the $i$ th pulse of methanol observed by the mass spectrum.
Temperature-programmed desorption, oxidation, and reaction experiments (TPD, TPO, and TPRx, respectively) were carried out in both the infrared cell and a quartz microreactor. Methanol was adsorbed from a mixture of $4 \%$ methanol in helium flowing at $30 \mathrm{~cm}^{3} \mathrm{~min}^{-1}$. A catalyst sample weighing $\sim 40 \mathrm{mg}$ was exposed to the methanol-containing gas at $323 \mathrm{~K}$ for $3 \mathrm{~min}$. A short exposure time was used to minimize the loss of vanadium from the catalyst. ${ }^{7}$ Following adsorption, the reactor was purged with a flow of $100 \mathrm{~cm}^{3} \mathrm{~min}^{-1}$ of $\mathrm{He}$ for at least $45 \mathrm{~min}$ to remove any residual gas-phase methanol. For TPD experiments, the samples were then heated in He flowing at $30 \mathrm{~cm}^{3} \mathrm{~min}^{-1}$, whereas for TPO experiments, the samples were heated in a $5 \% \mathrm{O}_{2} / \mathrm{He}$ mixture flowing at $30 \mathrm{~cm}^{3} \mathrm{~min}^{-1}$. For TPRx experiments, the samples were exposed to a mixture of $6 \%$ $\mathrm{MeOH} / 12 \% \mathrm{O}_{2} / \mathrm{He}$ flowing at $30 \mathrm{~cm}^{3} \mathrm{~min}^{-1}$. For all three types of experiment, the temperature was ramped from 323 to $773 \mathrm{~K}$ at $4 \mathrm{~K} / \mathrm{min}$. Infrared spectra were collected every $75 \mathrm{~s}$ to obtain a scan every $5 \mathrm{~K}$. The effluent from both the infrared cell and the microreactor was analyzed by an MKS Mini-Lab quadrupole mass spectrometer. Data were collected for 27 masses every $7.5 \mathrm{~s}$. Response factors and fragmentation patterns were determined for $\mathrm{H}_{2}, \mathrm{H}_{2} \mathrm{O}, \mathrm{O} 2, \mathrm{CO}, \mathrm{CO}_{2}, \mathrm{CH}_{3} \mathrm{OH}, \mathrm{CH}_{2} \mathrm{O}$, $\mathrm{CH}_{3} \mathrm{OCH}_{3}$, and $\mathrm{CH}_{4}$ relative to the $\mathrm{He}$ signal, which was used as an internal standard, and the values were adjusted to account for the isotopic abundance of both carbon and oxygen. Because the fragmentation pattern of methanol, formaldehyde, oxygen, and carbon monoxide produces overlapping peaks in the range of $m / e=28-33$, a matrix deconvolution procedure was used to quantify the gas-phase contributions of each species. After analysis, the data were smoothed using adjacent-averaging of 15 points.

X-ray absorption (XAS) measurements were performed at the Stanford Synchrotron Radiation Laboratory (SSRL) on beam line 2-3. These measurements were performed at the vanadium $\mathrm{K}$-edge. The edge energy for each sample was determined as the first inflection point of the main peak in the spectrum, and the edge energy of the vanadium foil was set to $5465 \mathrm{eV}$. The optimal sample amount was calculated on the basis of the weight fraction of all atomic species to obtain an absorbance of $\sim 2.5$, with boron nitride added if necessary to make a stable pellet. Samples were placed in a controlled-atmosphere cell that allowed for heating to $823 \mathrm{~K}$ in the presence of flowing gas. ${ }^{14}$ The $\mathrm{V} / \mathrm{TiO}_{2}$ sample was pretreated for $2 \mathrm{~h}$ at $773 \mathrm{~K}$ in $10 \%$ $\mathrm{O}_{2} /$ He flowing at $30 \mathrm{~cm}^{3} \mathrm{~min}^{-1}$. After the pretreatment was completed, the cell was evacuated to $6 \times 10^{-4} \mathrm{~Pa}$ and cooled to $77 \mathrm{~K}$ before the XAS data were collected.

The software program IFEFFIT, along with its complementary GUIs Athena and Artemis, were used for the data analysis. ${ }^{15,16}$ First, a linear pre-edge was subtracted from the data, fit to the range of -150 to $-75 \mathrm{eV}$ relative to the edge energy. Next, a quadratic polynomial fit to the range of $100-300 \mathrm{eV}$, relative to the edge energy, was used to determine the postedge line. The difference between the two lines at the edge energy was set to 1 to normalize the data.

\section{Results and Discussion}

Catalyst Characterization. Figure 1 shows the Raman spectra for both $\mathrm{TiO}_{2}$ and $\mathrm{V} / \mathrm{TiO}_{2}$ after dehydration in synthetic air at $773 \mathrm{~K}$ for $2 \mathrm{~h}$. The sharp peaks at 146, 197, 397, 516, and $640 \mathrm{~cm}^{-1}$, as well as the small peak at $800 \mathrm{~cm}^{-1}$, are present in both the pure $\mathrm{TiO}_{2}$ and the $\mathrm{V} / \mathrm{TiO}_{2}$ samples and are attributed to vibrations of the anatase crystal lattice. ${ }^{17}$ Upon addition of vanadium, a new broad band centered at $1025 \mathrm{~cm}^{-1}$ appears. This band is attributed to $\mathrm{V}=\mathrm{O}$ symmetric stretching vibrations 

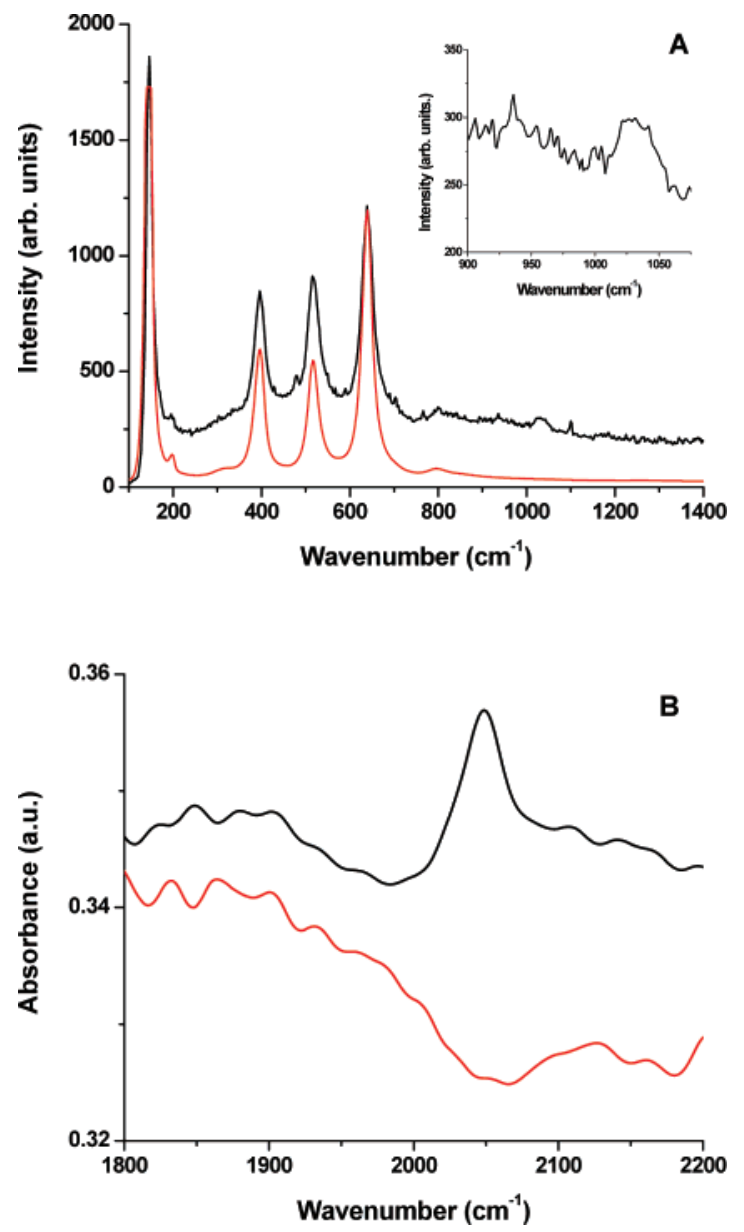

Figure 1. Raman (A) and infrared (B) spectra of $\mathrm{V} / \mathrm{TiO}_{2}$ (black) and $\mathrm{TiO}_{2}$ (red) after dehydration in dry air at $773 \mathrm{~K}$ for $2 \mathrm{~h}$. Inset in Raman plot shows the difference between $\mathrm{V} / \mathrm{TiO}_{2}$ and $\mathrm{TiO}_{2}$ in the region between 900 and $1075 \mathrm{~cm}^{-1}$.

in isolated $\mathrm{VO}_{4}$ units on anatase. ${ }^{6,18}$ Also shown in Figure 1 is the infrared spectrum of $\mathrm{V} / \mathrm{TiO}_{2}$ taken after dehydration. The peak at $2051 \mathrm{~cm}^{-1}$, which is not observed for $\mathrm{TiO}_{2}$, is assigned to the overtone of the symmetric stretch of $\mathrm{V}=\mathrm{O}$ in isolated $\mathrm{VO}_{4}$ units of the support. ${ }^{5,19}$ The absence of Raman peaks at 995, 704, 529, 288, and $147 \mathrm{~cm}^{-1}$ and infrared bands at 1970 and $2012 \mathrm{~cm}^{-1}$ indicates that the sample does not contain any nanocrystals of $\mathrm{V}_{2} \mathrm{O}_{5}$.

$\mathrm{X}$-ray absorption experiments were performed to identify the oxidation state and local structure of the vanadium centers dispersed on the anatase. Figure 2 shows the normalized XANES spectrum of $\mathrm{V} / \mathrm{TiO}_{2}$ after calcination. XANES spectra for $\mathrm{NaVO}_{3}$ and $\mathrm{V}_{2} \mathrm{O}_{5}$ are also shown for reference. For calcined $\mathrm{V} / \mathrm{TiO}_{2}$, the edge energy is $5484.3 \mathrm{eV}$. This value lies between the edge energies for $\mathrm{V}^{5+}$ in $\mathrm{NaVO}_{3}$ at $5483.5 \mathrm{eV}$ and $\mathrm{V}_{2} \mathrm{O}_{5}$ at $5484.8 \mathrm{eV}$, strongly suggesting that after calcination the oxidation state of the $\mathrm{V} / \mathrm{TiO}_{2}$ is +5 .

Vanadium in $\mathrm{NaVO}_{3}$ has tetrahedral symmetry, whereas the $\mathrm{V}$ in $\mathrm{V}_{2} \mathrm{O}_{5}$ has square planar or distorted octahedral symmetry. The height of the pre-edge peak at $5470 \mathrm{eV}$ can be used to determine the coordination of the vanadium atom if the standards and samples have the same formal oxidation state and the same ligands in the first coordination shell. This peak is attributed to electron transitions from the vanadium 1 s to $3 \mathrm{~d}$ level, ${ }^{20}$ which are spin forbidden and therefore should be weak. However, when the geometry around the vanadium atom becomes noncentrosymmetric, mixing between the oxygen $2 p$ and the vanadium $3 \mathrm{~d}$ levels can occur, leading to an increase in the observed

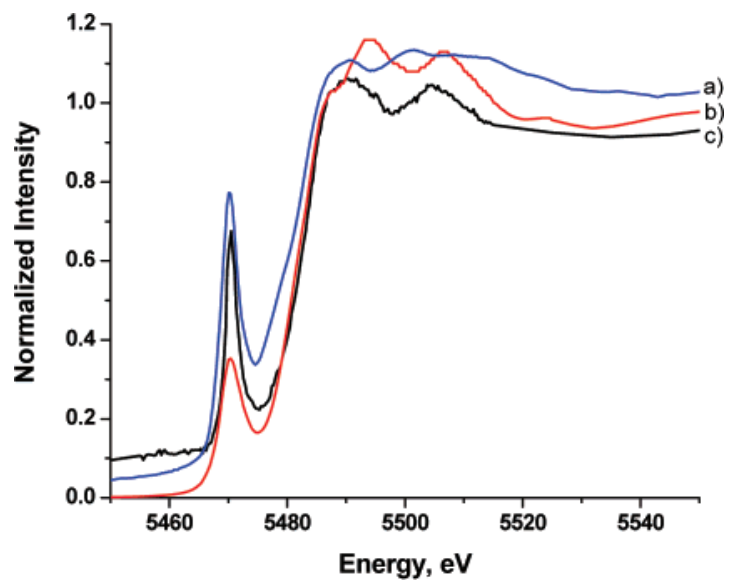

Figure 2. Normalized XANES spectra of (a) $\mathrm{NaVO}_{3}$, (b) $\mathrm{V}_{2} \mathrm{O}_{5}$, and (c) $\mathrm{V} / \mathrm{TiO}_{2}$.

intensity. This means that a purely octahedral geometry will have almost no pre-edge feature, whereas tetrahedrally coordinated $\mathrm{V}$ will have a large pre-edge feature. Based on a comparison to the geometry of the standards, the calcined $\mathrm{V} / \mathrm{TiO}_{2}$ has a distorted tetrahedral geometry similar to that of $\mathrm{NaVO}_{3}$.

Interactions of Methanol with $\mathrm{TiO}_{2}$. The infrared spectrum of $\mathrm{TiO}_{2}$ taken during methanol adsorption is shown in Figure 3. Upon methanol exposure, new features appear at 1440, 1460, $1640,2822,2833,2922$, and $2946 \mathrm{~cm}^{-1}$. After purging in $\mathrm{He}$ to remove gas-phase methanol, the intensities of the features at 1460, 2833, and $2946 \mathrm{~cm}^{-1}$ diminish continually, suggesting that these features are due to molecularly adsorbed methanol. These species are likely formed by the reaction of methanol with Lewis acid centers on the surface of anatase. The peaks at 1440, 2822, and $2922 \mathrm{~cm}^{-1}$ do not change in intensity during the He purge and are therefore assigned to surface methoxide groups on the titania surface. ${ }^{21}$ The methoxide species are formed by the reaction of methanol with $\mathrm{Ti}-\mathrm{O}-\mathrm{Ti}$ linkages to form $\mathrm{Ti}-\mathrm{OCH}_{3} / \mathrm{Ti}-\mathrm{OH}$ pairs. It was also observed that the isolated hydroxyl groups, characterized by a sharp peak at 3660 $\mathrm{cm}^{-1}$, disappeared upon methanol adsorption and that a broad feature between 3100 and $3400 \mathrm{~cm}^{-1}$ appeared. This feature has been attributed to hydrogen-bonding surface hydroxyl groups. ${ }^{22}$ The peak observed at $1640 \mathrm{~cm}^{-1}$ is attributed to a small amount of water in the gas phase that was removed from the sample during the addition of methanol.

Infrared spectra recorded during the TPD of methanol adsorbed on $\mathrm{TiO}_{2}$ are presented in Figure 4, and assignments of the observed bands are given in Table 1. The intensities of the $\mathrm{Ti}-\mathrm{OCH}_{3}$ bands are seen to decrease monotonically as the temperature increases and the positions of the bands shift to higher wavenumbers, due likely to the decrease in hydrogen bonding as the surface coverage is decreased. There are no residual methoxide species present on the surface at $773 \mathrm{~K}$, indicating that all of the adsorbed methoxide species have been removed by this temperature.

As seen in Figure 5, the primary products observed below $500 \mathrm{~K}$ during the TPD of methanol adsorbed on anatase are $\mathrm{CH}_{3} \mathrm{OH}$ and $\mathrm{H}_{2} \mathrm{O}$. The release of $\mathrm{CH}_{3} \mathrm{OH}$ is attributed to desorption of the small amount of molecularly adsorbed $\mathrm{CH}_{3} \mathrm{OH}$ and to recombination of $\mathrm{Ti}-\mathrm{OCH}_{3} / \mathrm{Ti}-\mathrm{OH}$ pairs. The formation of $\mathrm{H}_{2} \mathrm{O}$ is ascribed to the condensation of pairs of $\mathrm{Ti}-\mathrm{OH}$ groups and leads to an increase in the ratio of $\mathrm{Ti}-$ $\mathrm{OCH}_{3}$ to $\mathrm{Ti}-\mathrm{OH}$ groups remaining on the surface of anatase above $500 \mathrm{~K}$. A very broad formaldehyde peak is also observed in the TPD spectrum below $500 \mathrm{~K}$, which may be formed by 

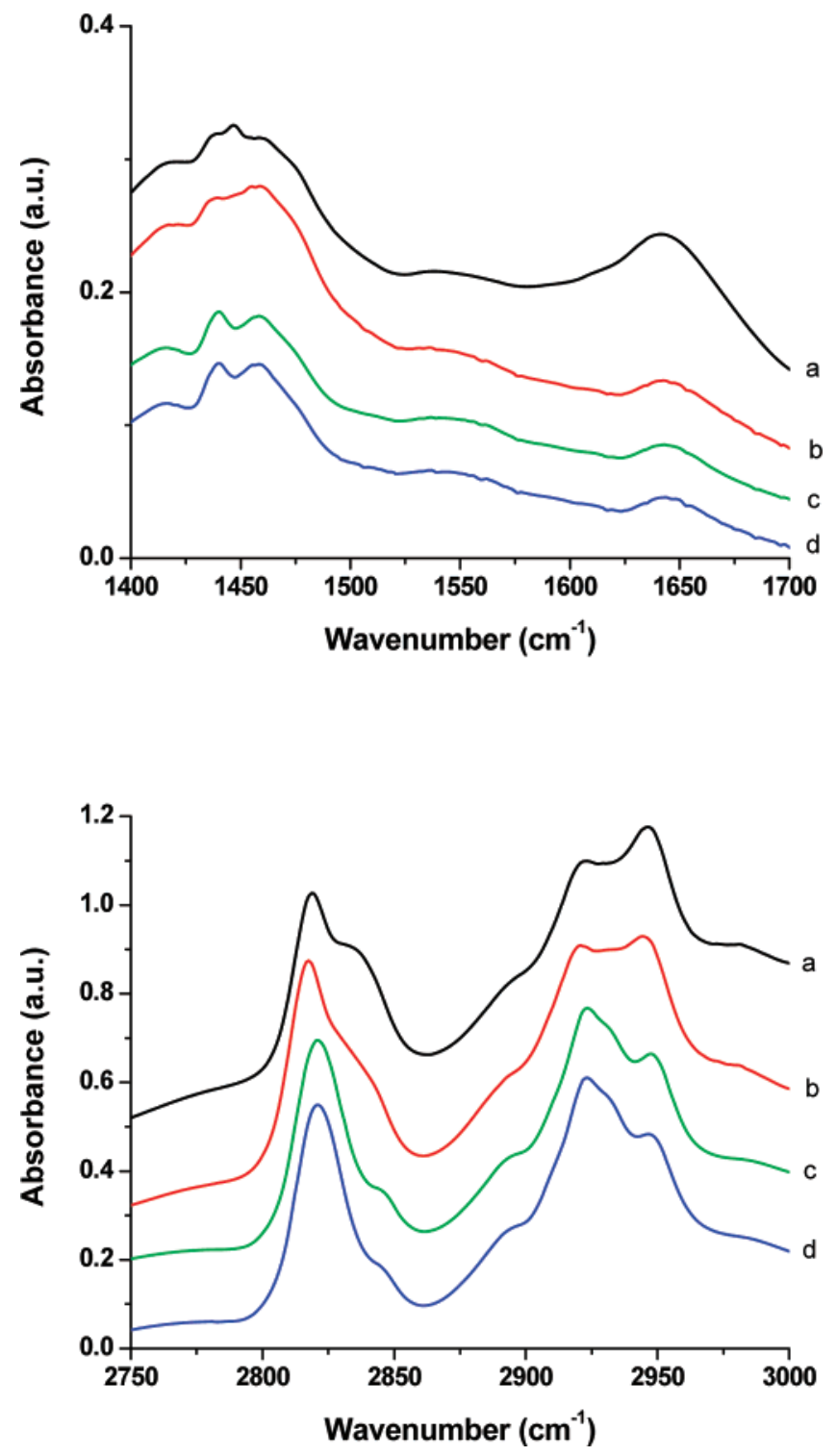

Figure 3. Low and high wavenumber infrared spectra of $\mathrm{TiO}_{2}$ taken during methanol adsorption at $323 \mathrm{~K}$ and subsequent He purge. (a) After $1 \mathrm{~min}$ in methanol, (b) after $3 \mathrm{~min}$ in methanol, (c) after He purge for $2 \mathrm{~min}$, and (d) after He purge for $45 \mathrm{~min}$.

transfer of a proton from a $\mathrm{Ti}-\mathrm{OCH}_{3}$ group to form $\mathrm{CH}_{2} \mathrm{O}$ and a $\mathrm{Ti}-\mathrm{H}$ group. The reaction of this surface hydride with a $\mathrm{Ti}-$ $\mathrm{OH}$ group could also contribute to the formation of $\mathrm{H}_{2} \mathrm{O}$, creating an oxygen vacancy at the surface of anatase. $\mathrm{CH}_{3} \mathrm{OH}$ and $\mathrm{H}_{2} \mathrm{O}$ continue to desorb above $500 \mathrm{~K}$ but are now accompanied by additional products. DME appears above 500 $\mathrm{K}, \mathrm{CH}_{4}$ and $\mathrm{CO}$ appear above $575 \mathrm{~K}$, and $\mathrm{H}_{2}$ appears above $600 \mathrm{~K}$. The formation of DME is attributable to the condensation of two $\mathrm{Ti}-\mathrm{OCH}_{3}$ groups, whereas the formation of $\mathrm{CH}_{4}$ is ascribed to the reaction of $\mathrm{Ti}-\mathrm{OCH}_{3}$ groups with $\mathrm{Ti}-\mathrm{H}$ groups. The $\mathrm{Ti}-\mathrm{H}$ groups required for the formation of $\mathrm{CH}_{4}$ most likely come from the decomposition of isolated $\mathrm{Ti}-\mathrm{OCH}_{3}$ groups, a process which would also release CO. Finally, the formation of $\mathrm{H}_{2}$ is likely due to the reaction of pairs of $\mathrm{Ti}-\mathrm{H}$ groups. The products formed in the present study and the temperatures of their appearance are very similar to those reported by Kim et al. ${ }^{8}$ for methanol adsorbed on low-surface area anatase.

Assuming that the infrared absorption coefficients for $\mathrm{C}-\mathrm{H}$ stretching vibrations associated with molecularly adsorbed $\mathrm{CH}_{3} \mathrm{OH}$ and $\mathrm{Ti}-\mathrm{OCH}_{3}$ groups are the same, it is estimated that following a He purge at $323 \mathrm{~K}$ for $45 \mathrm{~min}, 90 \%$ of the methanol
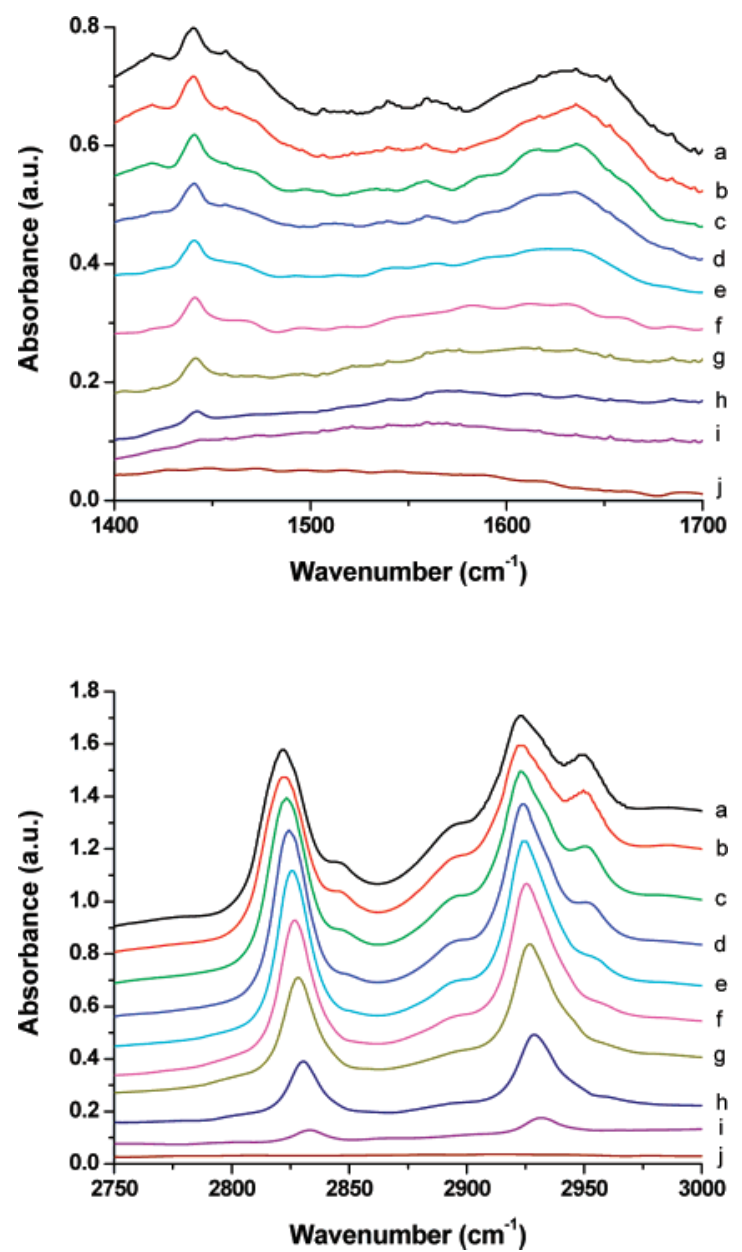

Figure 4. Low and high wavenumber infrared spectra of $\mathrm{TiO}_{2}$ taken during TPD of adsorbed methanol. Flow rate of He: $30 \mathrm{~cm}^{3} \mathrm{~min}^{-1}$. (a) $323 \mathrm{~K}$, (b) $373 \mathrm{~K}$, (c) $423 \mathrm{~K}$, (d) $473 \mathrm{~K}$, (e) $523 \mathrm{~K}$, (f) $573 \mathrm{~K}$, (g) 623 K, (h) $673 \mathrm{~K}$, (i) $723 \mathrm{~K}$, (j) $773 \mathrm{~K}$.

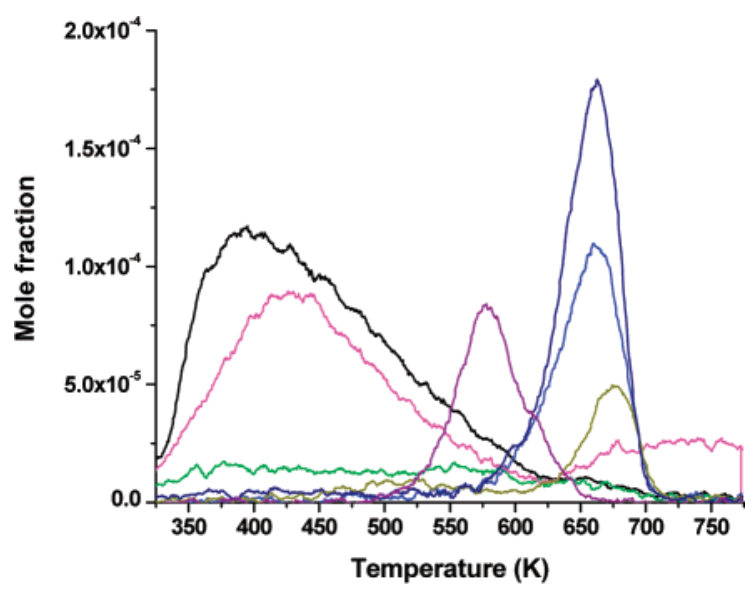

Figure 5. Gas-phase concentrations observed during TPD of methanol adsorbed on $\mathrm{TiO}_{2}$. Flow rate of $\mathrm{He}: 30 \mathrm{~cm}^{3} \mathrm{~min}^{-1}$. Methanol-black, formaldehyde-green, water-pink, carbon monoxide-blue, hydrogen-gold, methane-navy, dimethylether-purple.

adsorbed on anatase is in the form of $\mathrm{Ti}-\mathrm{OCH}_{3}$ and $10 \%$ is in the form of molecularly adsorbed $\mathrm{CH}_{3} \mathrm{OH}$. The total amount of methanol adsorbed at $323 \mathrm{~K}$ can be determined from the amount of carbon removed from the catalyst during TPD or TPO. Table 2 shows that this amount corresponds to $\sim 2.6$ molecules of $\mathrm{CH}_{3} \mathrm{OH} / \mathrm{nm}^{2}$, in very close agreement with the amount of adsorbed $\mathrm{CH}_{3} \mathrm{OH}$ determined from pulsed adsorption measurements. The surface concentration of methanol observed in the 
TABLE 1: Assignment of Infrared Bands Detected on the Surface of Anatase and $\mathrm{V} / \mathrm{TiO}_{2}{ }^{a}$

\begin{tabular}{llll}
\hline & $\mathrm{Ti}-\mathrm{OCH}_{3}$ & $\mathrm{~V}-\mathrm{OCH}_{3}$ & ads. $\mathrm{CH}_{3} \mathrm{OH}$ \\
\hline$\delta \mathrm{C}-\mathrm{H}$ & $1440-1443$ & $1435-1436$ & $1460-1463$ \\
$v_{\text {asym }} \mathrm{O}-\mathrm{C}-\mathrm{O}$ & 1570 & $1575(\mathrm{TPD})$ & \\
& & $1555(\mathrm{TPO})$ & \\
$v_{\text {sym }} \mathrm{C}-\mathrm{H}$ & $2819-2833$ & $\sim 2832$ & $2833-2850$ \\
$v_{\text {asym }} \mathrm{C}-\mathrm{H}$ & $2921-2932$ & $2929-2939$ & $2945-2956$
\end{tabular}

${ }^{a}$ A range is given for each assignment due to the shift in the peak positions at different temperatures or surface coverages.

present study is only slightly less than the value of 3.14 molecules of $\mathrm{CH}_{3} \mathrm{OH} / \mathrm{nm}^{2}$ reported by $\mathrm{Kim}$ et al. ${ }^{8}$ for anatase having a surface area of $10.3 \mathrm{~m}^{2} / \mathrm{g}$. From these measurements, it is calculated that $\sim 48 \%$ of the surface $\mathrm{Ti}$ atoms are involved with the dissociative adsorption of methanol to form $\mathrm{Ti}-\mathrm{OCH}_{3} /$ $\mathrm{Ti}-\mathrm{OH}$ pairs. ${ }^{23}$ The total amount of $\mathrm{H}$ present in all desorbing species is approximately 4 times that of the total amount of $\mathrm{C}$ present in all of the desorbing species, indicating that all of the $\mathrm{C}$ and $\mathrm{H}$ in the desorbing products originate from adsorbed $\mathrm{CH}_{3} \mathrm{OH}$. However, the total amount of $\mathrm{O}$ present in all desorbing species, $2.79 \mathrm{O} / \mathrm{nm}^{2}$, is somewhat greater than the amount of $\mathrm{O}$ associated with the adsorbed $\mathrm{CH}_{3} \mathrm{OH}, 2.62 \mathrm{O} / \mathrm{nm}^{2}$, indicating that during TPD $0.17 \mathrm{O} / \mathrm{nm}^{2}$ are abstracted from the surface of anatase.

Infrared spectra recorded during the TPO of methanol adsorbed on $\mathrm{TiO}_{2}$ are shown in Figure 6, and the composition of gas-phase species produced during this process is presented in Figure 7. Comparison of Figures 5 and 7 reveals that below $500 \mathrm{~K}$ the TPO spectrum of $\mathrm{CH}_{3} \mathrm{OH}$ adsorbed on anatase is very similar to the corresponding TPD spectrum. Here too $\mathrm{CH}_{3}-$ $\mathrm{OH}$ and $\mathrm{H}_{2} \mathrm{O}$ are observed as the principal desorption products, together with a small amount of $\mathrm{CH}_{2} \mathrm{O}$. The principal differences between the TPO and TPD spectra occur above $500 \mathrm{~K}$. The formation of DME during TPO begins above $500 \mathrm{~K}$, and reaches a maximum at $580 \mathrm{~K}$ similar to DME formation during TPD, but the total amount of DME is only about $30 \%$ of that observed during TPD. However, over this temperature range large amounts of $\mathrm{CO}$ and $\mathrm{H}_{2} \mathrm{O}$ are observed, which very likely are formed by combustion of nascent DME. The higher concentration of $\mathrm{H}_{2} \mathrm{O}$ in the temperature interval of 500-600 K observed during TPO than TPD appears to contribute to a burst in the formation of $\mathrm{CH}_{3} \mathrm{OH}$ as a result of hydrolysis of some isolated $\mathrm{Ti}-\mathrm{OCH}_{3}$ groups. Above $600 \mathrm{~K}$ the remaining $\mathrm{Ti}-\mathrm{OCH}_{3}$ groups undergo combustion to form $\mathrm{CO}$ and $\mathrm{H}_{2} \mathrm{O}$. Some $\mathrm{H}_{2}$ is also observed, but there is no evidence for methane formation during TPO.

The infrared spectrum taken during TPO (Figure 6) shows a broad feature at $1575 \mathrm{~cm}^{-1}$. This band, which first appears at $523 \mathrm{~K}$ and then disappears above $673 \mathrm{~K}$, is attributed to the formation of formate species on the surface of $\mathrm{TiO}_{2} \cdot{ }^{24}$ Because these formate species were not observed during TPD, it is likely that they are formed by the oxidization of surface methoxide species in the presence of gas-phase oxygen and are likely intermediates in the formation of $\mathrm{CO}$ and $\mathrm{H}_{2} \mathrm{O}$ above $600 \mathrm{~K}$. As in the case of TPD, the ratio of $\mathrm{H} / \mathrm{C}$ in the product formed during TPO is again close to 4 , indicating that all of the $\mathrm{C}$ and $\mathrm{H}$ appearing in the products arises from adsorbed $\mathrm{CH}_{3} \mathrm{OH}$. However, during TPO the $\mathrm{O} / \mathrm{C}$ ratio of the desorbing products is 1.8 , indicating that $0.8 \mathrm{O} / \mathrm{C}$ is obtained from $\mathrm{O}_{2}$. It is also noted that during TPD and TPO approximately $40 \%$ of the adsorbed methanol desorbs as $\mathrm{CH}_{3} \mathrm{OH}$.

Infrared spectra recorded during the TPRx of methanol adsorbed on $\mathrm{TiO}_{2}$ are shown in Figure 8, and the composition of gas-phase species produced during this process is shown in Figure 9. A mixture of $6 \% \mathrm{MeOH} / 12 \% \quad \mathrm{O}_{2} /$ balance $\mathrm{He}$ was flowed over the catalyst as the temperature was ramped from 373 to $773 \mathrm{~K}$. A comparison of Figures 6 and 8 shows that the infrared features are nearly the same as those observed during TPO, indicating that surface formate species are present during TPRx at temperatures between 473 and $673 \mathrm{~K}$. This suggests that the same surface processes occur during both TPO and TPRx. Under TPRx conditions, products are not produced at a significant rate below $475 \mathrm{~K}$. Between 475 and $580 \mathrm{~K}$, the main products are DME and $\mathrm{CH}_{2} \mathrm{O}$, with mainly $\mathrm{CH}_{2} \mathrm{O}$ formed initially and DME being formed in preference to $\mathrm{CH}_{2} \mathrm{O}$ above $565 \mathrm{~K}$. Above $580 \mathrm{~K} \mathrm{CO}$ is formed at an increasingly rapid rate. The formation of DME reaches a maximum at about 685 $\mathrm{K}$ and $\mathrm{CH}_{2} \mathrm{O}$ at about $720 \mathrm{~K}$. The formation of $\mathrm{H}_{2} \mathrm{O}$ begins at $475 \mathrm{~K}$ and accelerates once the formation of DME reaches a maximum. The trends seen in Figure 9 are very similar to those observed during TPO seen in Figure 7. Both sets of data and the TPD spectrum shown in Figure 5 indicate that anatase is a poor catalyst for the formation of $\mathrm{CH}_{2} \mathrm{O}$ from $\mathrm{Ti}-\mathrm{OCH}_{3}$ groups but a better catalyst for the condensation of these groups to DME. However, at temperatures above $700 \mathrm{~K}$, both unreacted $\mathrm{Ti}-\mathrm{OCH}_{3}$ groups and DME undergo complete combustion to form $\mathrm{CO}, \mathrm{CO}_{2}$, and $\mathrm{H}_{2} \mathrm{O}$.

Interactions of Methanol with $\mathbf{V} / \mathbf{T i O}_{2}$. Figure 10 shows infrared spectra taken during the adsorption of methanol on $\mathrm{V} / \mathrm{TiO}_{2}$. The peaks at 2841 and $2950 \mathrm{~cm}^{-1}$ disappear rapidly during the He purge and are, therefore, assigned to gas-phase methanol or very weakly physisorbed methanol. The bands that remain after the He purge are at 1434, 1449, 2827, 2850, 2922, 2932, and $2956 \mathrm{~cm}^{-1}$. The peak at $2922 \mathrm{~cm}^{-1}$ was previously observed on pure $\mathrm{TiO}_{2}$ and has been assigned to $\mathrm{Ti}-\mathrm{OCH}_{3}$ groups. Consequently, the feature at $2932 \mathrm{~cm}^{-1}$ is assigned to asymmetric $\mathrm{C}-\mathrm{H}$ vibrations of $\mathrm{V}-\mathrm{OCH}_{3}$ groups formed by the addition of $\mathrm{CH}_{3} \mathrm{OH}$ across $\mathrm{V}-\mathrm{O}-\mathrm{Ti}$ bonds. ${ }^{25}$ The band observed at $2827 \mathrm{~cm}^{-1}$ is likely due to symmetric $\mathrm{C}-\mathrm{H}$ vibrations associated with both $\mathrm{Ti}-\mathrm{OCH}_{3}$ and $\mathrm{V}-\mathrm{OCH}_{3}$ groups. Vibrations were observed for $\mathrm{Ti}-\mathrm{OCH}_{3}$ groups at $2822 \mathrm{~cm}^{-1}$, whereas Wachs and co-workers ${ }^{5}$ have observed a band for $\mathrm{V}-\mathrm{OCH}_{3}$ groups at $2832 \mathrm{~cm}^{-1}$ on a monolayer $\mathrm{V} / \mathrm{TiO}_{2}$. The loss of the peak at $3660 \mathrm{~cm}^{-1}$ for isolated $\mathrm{Ti}-\mathrm{OH}$ species during methanol addition, along with the formation of a broad feature

TABLE 2: Total Amounts of Each Product Released into the Gas Phase during TPD and TPO of Methanol Adsorbed on TiO and $\mathrm{V} / \mathrm{TiO}_{2}{ }^{a}$

\begin{tabular}{|c|c|c|c|c|c|c|c|c|c|c|c|c|c|}
\hline & & $\mathrm{CH}_{3} \mathrm{OH}$ & $\mathrm{CH}_{2} \mathrm{O}$ & $\mathrm{CO}$ & $\mathrm{CO}_{2}$ & $\mathrm{H}_{2} \mathrm{O}$ & $\mathrm{H}_{2}$ & $\mathrm{CH}_{4}$ & DME & total C & total $\mathrm{H}$ & total O & $\begin{array}{c}\mathrm{MeOH} \\
\text { adsorbed }\end{array}$ \\
\hline $\mathrm{TiO}_{2}$ & TPD & 1.02 & 0.22 & 0.37 & 0 & 0.92 & 0.18 & 0.49 & 0.26 & 2.62 & 10.27 & 2.79 & 2.60 \\
\hline $\mathrm{TiO}_{2}$ & TPO & 1.07 & 0.31 & 0.88 & 0.19 & 2.13 & 0.16 & 0 & 0.11 & 2.66 & 10.14 & 4.87 & 2.62 \\
\hline $\mathrm{V}-\mathrm{TiO}_{2}$ & TPD & 0.46 & 0.26 & 0.83 & 0.10 & 1.78 & 0.30 & 0.21 & 0.06 & 1.97 & 7.70 & 3.59 & 1.73 \\
\hline $\mathrm{V}-\mathrm{TiO}_{2}$ & TPO & 0.59 & 0.32 & 1.00 & 0.18 & 2.32 & 0 & 0 & 0 & 2.09 & 7.63 & 4.59 & 1.93 \\
\hline
\end{tabular}

${ }^{a}$ Also shown are the total amounts of carbon, hydrogen, and oxygen removed from the surface based on the species observed in the gas phase. The right-hand-most column is the amount of methanol adsorbed on the surface based on the methanol pulsing experiments. All quantities are in atoms $/ \mathrm{nm}^{2}$. 

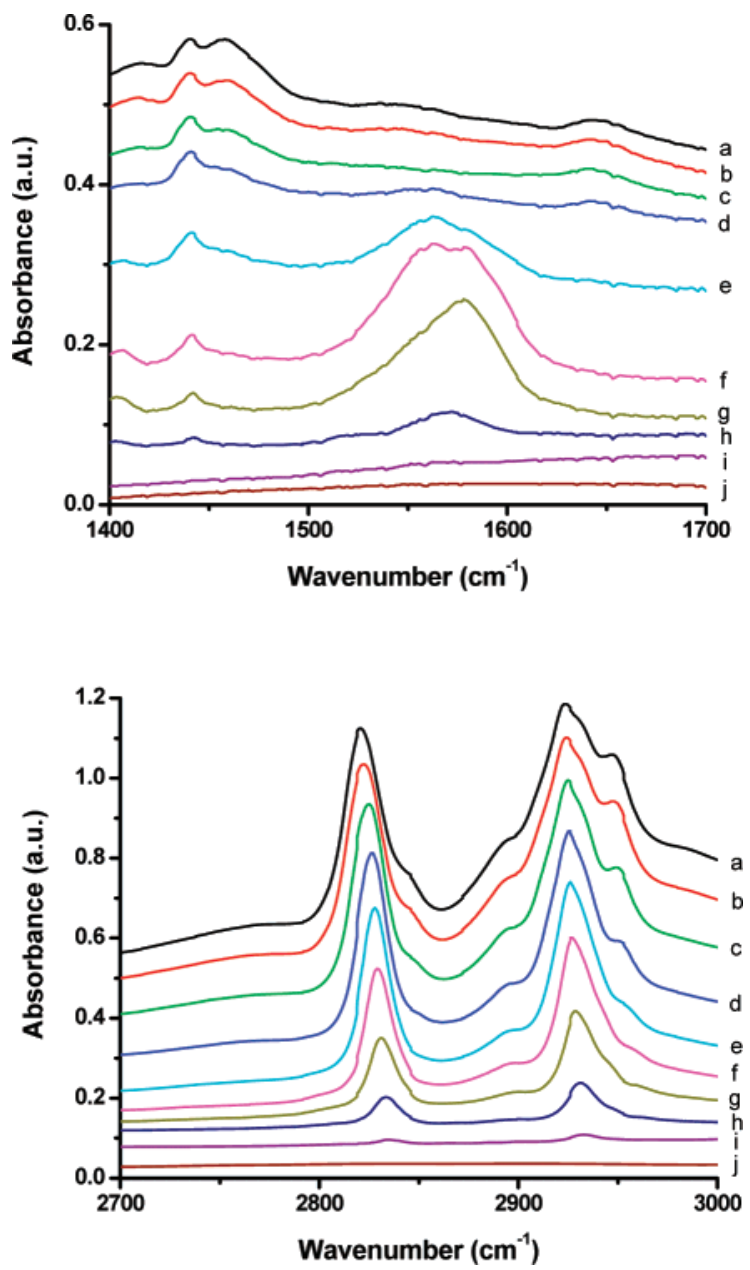

Figure 6. Low and high wavenumber infrared spectra of $\mathrm{TiO}_{2}$ taken during TPO of adsorbed methanol. Flow rate of $5 \% \mathrm{O}_{2} / \mathrm{He}: 30 \mathrm{~cm}^{3}$ $\min ^{-1}$. (a) $323 \mathrm{~K}$, (b) $373 \mathrm{~K}$, (c) $423 \mathrm{~K}$, (d) $473 \mathrm{~K}$, (e) $523 \mathrm{~K}$, (f) 573 K, (g) $623 \mathrm{~K}$, (h) $673 \mathrm{~K}$, (i) $723 \mathrm{~K}$, (j) $773 \mathrm{~K}$.

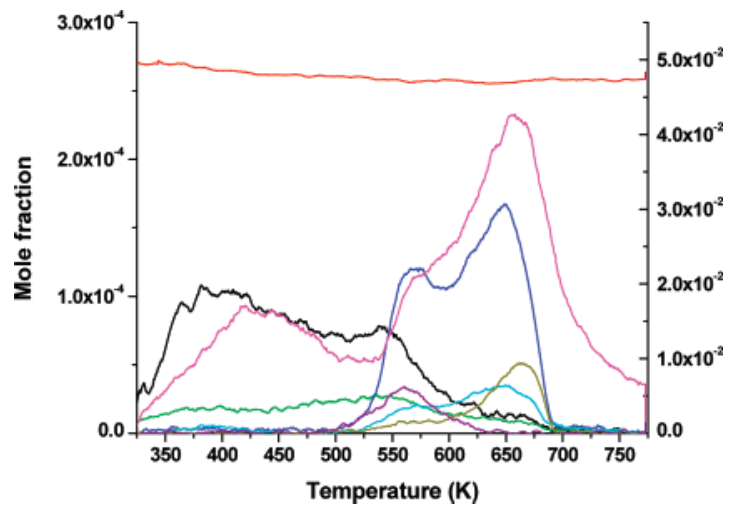

Figure 7. Gas-phase concentrations observed during TPO of methanol adsorbed on $\mathrm{TiO}_{2}$. Flow rate of $5 \% \mathrm{O}_{2} / \mathrm{He}: 30 \mathrm{~cm}^{3} \mathrm{~min}^{-1}$. Left axis: methanol-black, formaldehyde-green, water-pink, carbon monoxideblue, carbon dioxide-light blue, hydrogen-gold, dimethylether-purple. Right axis: oxygen-red.

from 3100 to $3400 \mathrm{~cm}^{-1}$, is attributed to the formation of hydrogen-bonding hydroxyl groups on the surface, as was observed for $\mathrm{TiO}_{2}$ (see above).

The infrared spectra presented in Figure 10 show that methanol adsorption on anatase containing $2 \mathrm{~V}$ atom $/ \mathrm{nm}^{2}$ occurs in three modes: as adsorbed $\mathrm{CH}_{3} \mathrm{OH}$, as $\mathrm{Ti}-\mathrm{OCH}_{3} / \mathrm{Ti}-\mathrm{OH}$ pairs, and as $\mathrm{V}-\mathrm{OCH}_{3} / \mathrm{Ti}-\mathrm{OH}$ pairs. While the formation of $\mathrm{V}-\mathrm{OH} / \mathrm{Ti}-\mathrm{OCH}_{3}$ pairs might also be considered, theoretical calculations suggest that the formation of $\mathrm{V}-\mathrm{OCH}_{3} / \mathrm{Ti}-\mathrm{OH}$
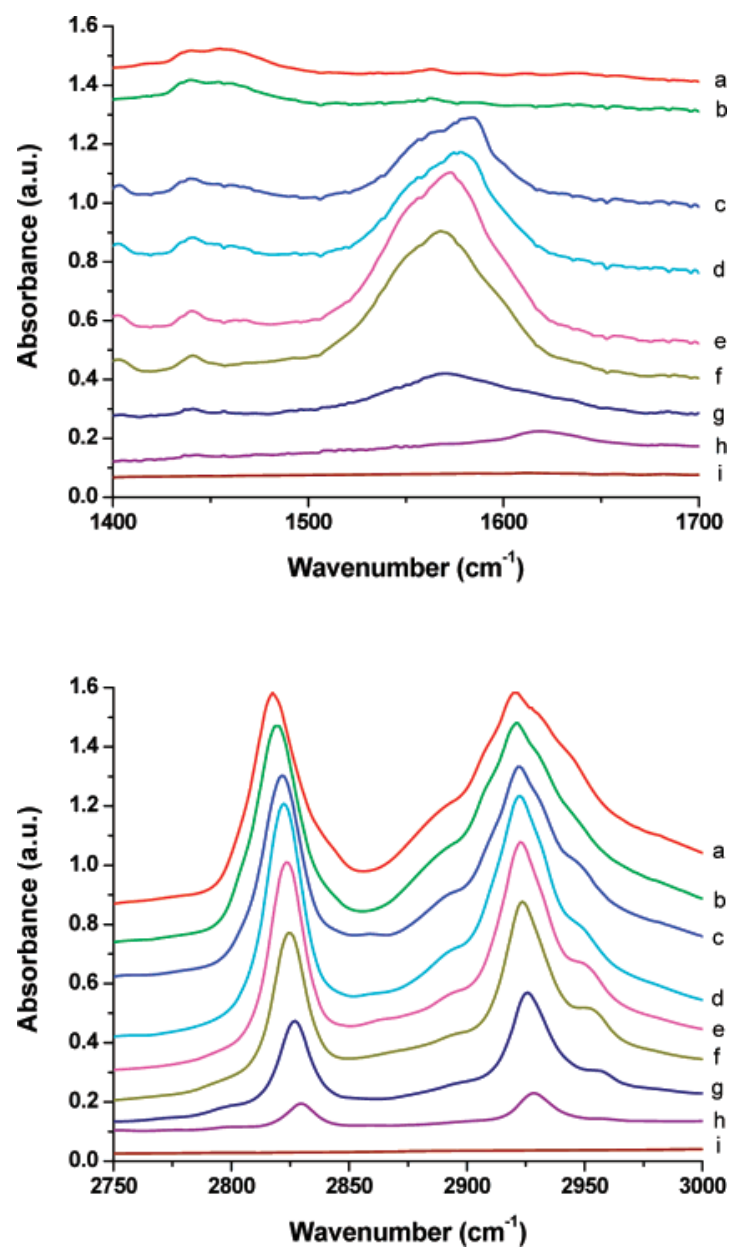

Figure 8. Low and high wavenumber infrared spectra of $\mathrm{TiO}_{2}$ taken during TPRx in $6 \% \mathrm{MeOH} / 12 \% \mathrm{O}_{2} / \mathrm{He}$ flowing at $30 \mathrm{~cm}^{3} \mathrm{~min}^{-1}$. (a) $373 \mathrm{~K}$, (b) $423 \mathrm{~K}$, (c) $473 \mathrm{~K}$, (d) $523 \mathrm{~K}$, (e) $573 \mathrm{~K}$, (f) $623 \mathrm{~K}$, (g) 673 K, (h) $723 \mathrm{~K}$, (i) $773 \mathrm{~K}$.

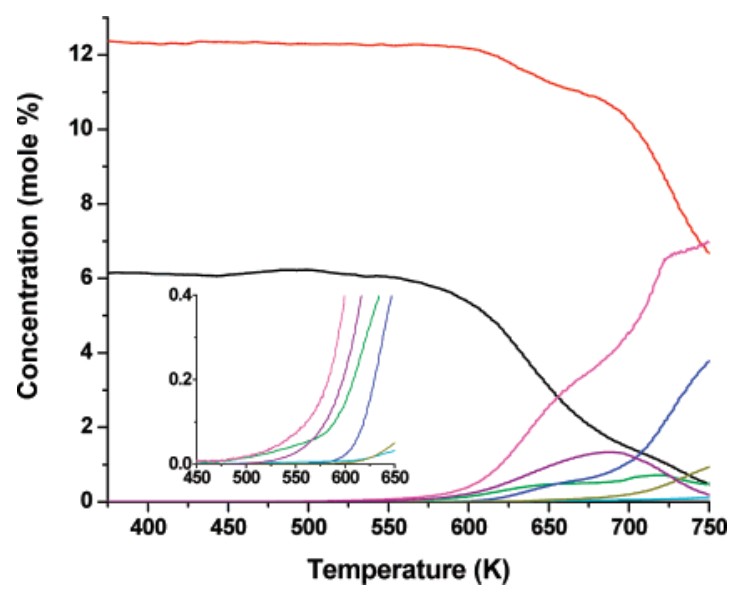

Figure 9. Gas-phase concentrations observed during TPRx of $\mathrm{TiO}_{2}$ in $6 \% \mathrm{MeOH} / 12 \% \mathrm{O}_{2} / \mathrm{He}$ flowing at $30 \mathrm{~cm}^{3} \mathrm{~min}^{-1}$. Methanol-black, oxygen-red, formaldehyde-green, water-pink, carbon monoxide-blue, carbon dioxide-light blue, hydrogen-gold, dimethylether-purple.

pairs is strongly preferred thermodynamically. ${ }^{26}$ As in the case of anatase alone, about $90 \%$ of the adsorbed methanol is present as methoxide groups and only $10 \%$ as molecularly adsorbed $\mathrm{CH}_{3} \mathrm{OH}$. Table 2 shows that the total amount of methanol adsorbed on $\mathrm{V} / \mathrm{TiO}_{2}$ is less than that adsorbed on $\mathrm{TiO}_{2}$ alone, $\sim 1.9$ molecules of $\mathrm{CH}_{3} \mathrm{OH} / \mathrm{nm}^{2}$ as compared to 2.6 molecules of $\mathrm{CH}_{3} \mathrm{OH} / \mathrm{nm}^{2}$. The lower surface concentration of adsorbed methanol on $\mathrm{V} / \mathrm{TiO}_{2}$ in comparison to $\mathrm{TiO}_{2}$ can be explained 

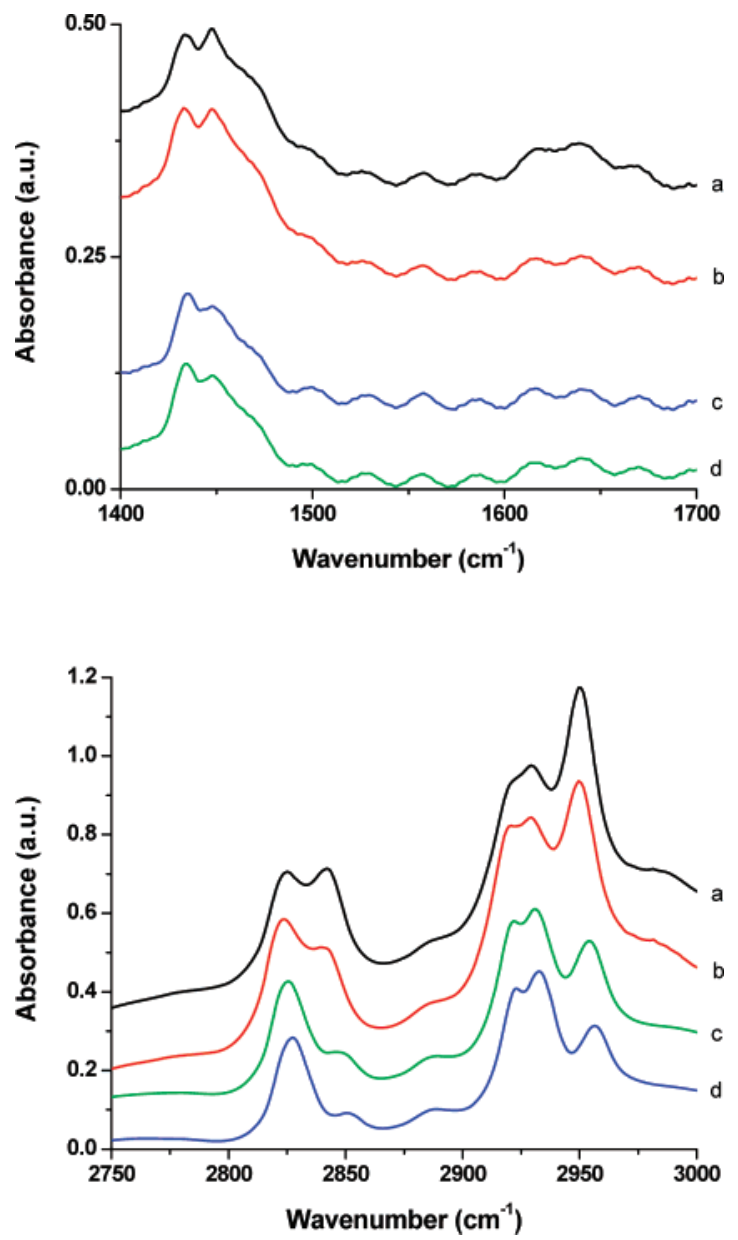

Figure 10. Low and high wavenumber infrared spectra of $\mathrm{V} / \mathrm{TiO}_{2}$ taken during methanol adsorption at $323 \mathrm{~K}$ and subsequent He purge. (a) After $1 \mathrm{~min}$ in methanol, (b) after 3 min in methanol, (c) after He purge for $2 \mathrm{~min}$, and (d) after He purge for $45 \mathrm{~min}$.

as follows. $\mathrm{TiO}_{2}$ contains $10.8 \mathrm{Ti}$ sites $/ \mathrm{nm}^{2}$, and, hence, it can be shown that there are also $10.8 \mathrm{O}$ atoms $/ \mathrm{nm}^{2}$ in $\mathrm{Ti}-\mathrm{O}-\mathrm{Ti}$ bonds on the surface of anatase. The introduction of $2.0 \mathrm{~V}$ atoms $/ \mathrm{nm}^{2}$ as isolated $\mathrm{VO}_{4}$ species, each of which grafts to 3 $\mathrm{O}$ atoms on the surface, reduces the surface concentration of $\mathrm{O}$ atoms in $\mathrm{Ti}-\mathrm{O}-\mathrm{Ti}$ bonds to $4.8 \mathrm{O}$ atom $/ \mathrm{nm}^{2}$. If it is assumed that only one $\mathrm{V}-\mathrm{O}-\mathrm{Ti}$ bond per $\mathrm{V}$ center is able to react with methanol and that only $48 \%$ of the $\mathrm{Ti}-\mathrm{O}-\mathrm{Ti}$ and $\mathrm{V}-\mathrm{O}-\mathrm{Ti}$ bonds undergo methanolysis, the same percentage observed on anatase, then the predicted surface coverage of all methoxide species (both Ti- $\mathrm{OCH}_{3}$ and $\mathrm{V}-\mathrm{OCH}_{3}$ ) is predicted to decrease from 2.6 methoxide species $/ \mathrm{nm}^{2}$ for $\mathrm{TiO}_{2}$ to 2.1 methoxide species $/ \mathrm{nm}^{2}$ for $\mathrm{V} / \mathrm{TiO}_{2}$, in reasonable agreement with what is seen in Table 2. Using the same assumptions leads to the expectation of approximately equivalent concentrations of $\mathrm{Ti}-$ $\mathrm{OCH}_{3}$ and $\mathrm{V}-\mathrm{OCH}_{3}$, which also matches what is seen by infrared spectroscopy at $323 \mathrm{~K}$ after He purge (see Figure 10).

Infrared spectra recorded during TPD of methanol adsorbed on $\mathrm{V} / \mathrm{TiO}_{2}$ are presented in Figure 11. With increasing temperature, the bands for $\mathrm{Ti}-\mathrm{OCH}_{3}$ groups diminish more rapidly than those for $\mathrm{V}-\mathrm{OCH}_{3}$ groups. At temperatures between 423 and $673 \mathrm{~K}$, a sharp peak appears at $1575 \mathrm{~cm}^{-1}$ along with four overlapping bands in the region between 1340 and $1400 \mathrm{~cm}^{-1}$ and two weak bands at 2880 and $2898 \mathrm{~cm}^{-1}$. These peaks are assigned to surface formate species. The band at $1575 \mathrm{~cm}^{-1}$ is similar to that observed at $1570 \mathrm{~cm}^{-1}$ during TPO on $\mathrm{TiO}_{2}$. The weak bands in the $1340-1400 \mathrm{~cm}^{-1}$ region are only observed on $\mathrm{V} / \mathrm{TiO}_{2}$ due to the large concentration of formate
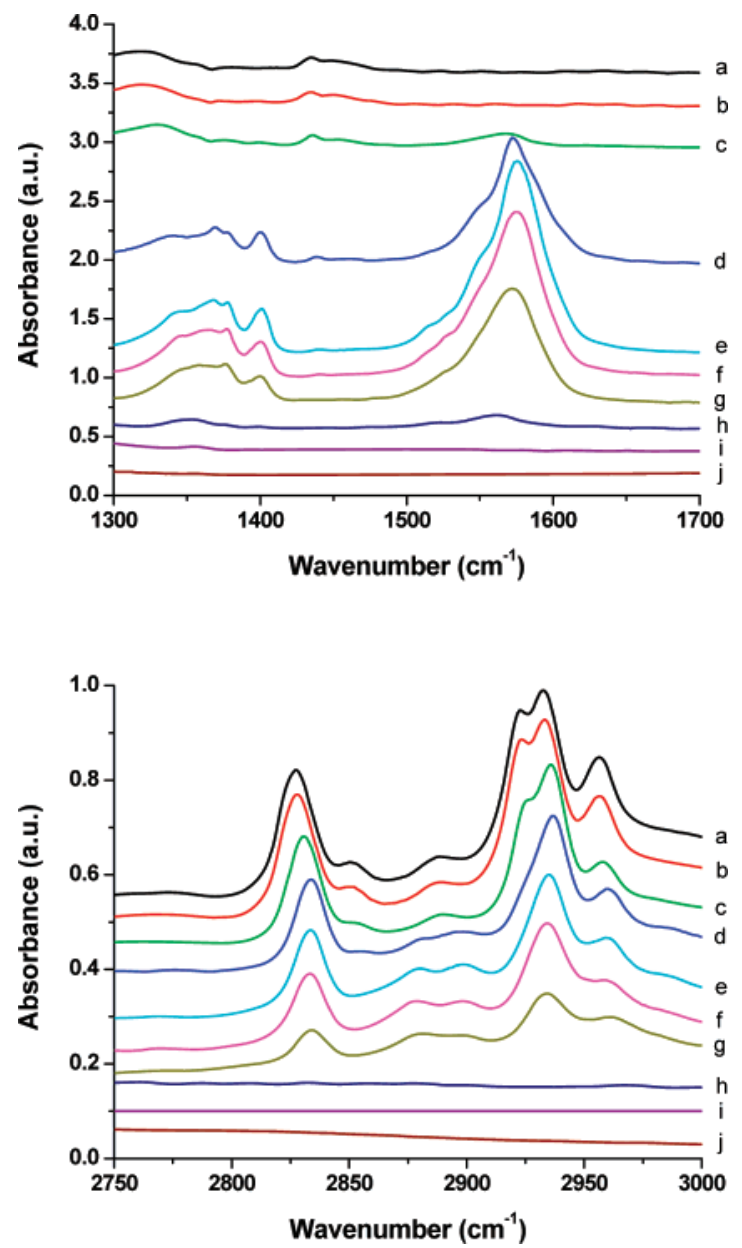

Figure 11. Low and high wavenumber infrared spectra of $\mathrm{V} / \mathrm{TiO}_{2}$ taken during TPD of adsorbed methanol. Flow rate of $\mathrm{He}: 30 \mathrm{~cm}^{3} \mathrm{~min}^{-1}$. (a) $323 \mathrm{~K}$, (b) $373 \mathrm{~K}$, (c) $423 \mathrm{~K}$, (d) $473 \mathrm{~K}$, (e) $523 \mathrm{~K}$, (f) $573 \mathrm{~K}$, (g) 623 K, (h) $673 \mathrm{~K}$, (i) $723 \mathrm{~K}$, (j) $773 \mathrm{~K}$.

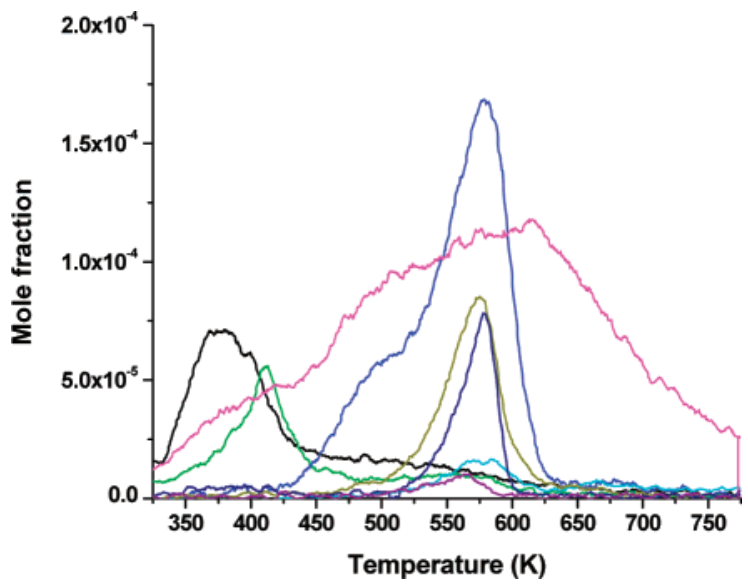

Figure 12. Gas-phase concentrations observed during TPD of methanol adsorbed on $\mathrm{V} / \mathrm{TiO}_{2}$. Flow rate of $\mathrm{He}: 30 \mathrm{~cm}^{3} \mathrm{~min}^{-1}$. Methanol-black, formaldehyde-green, water-pink, carbon monoxide-blue, carbon dioxidelight blue, hydrogen-gold, methane-navy, dimethylether-purple.

species present under these conditions, and decrease in intensity at the same rate as the large band at $1575 \mathrm{~cm}^{-1}$.

Comparison of the TPD spectrum for methanol adsorbed on $\mathrm{V} / \mathrm{TiO}_{2}$, shown in Figure 12, with that for $\mathrm{TiO}_{2}$, shown in Figure 5 , reveals several significant differences. While $\mathrm{CH}_{3} \mathrm{OH}$ and $\mathrm{H}_{2} \mathrm{O}$ both appear in the gas phase at temperatures above 350 $\mathrm{K}$, the rates at which these products are formed are lower when isolated vanadate species are present on the surface of the 
support. It is also evident that in this case a well-defined peak of $\mathrm{CH}_{2} \mathrm{O}$ appears at about $410 \mathrm{~K}$. This low-temperature peak is attributed to the reaction of $\mathrm{V}-\mathrm{OCH}_{3}$ species, because it was not observed during TPD of methanol adsorbed on $\mathrm{TiO}_{2}$. Theoretical studies have shown that $\mathrm{CH}_{2} \mathrm{O}$ is formed by transfer of an $\mathrm{H}$ atom from the methyl group of $\mathrm{V}-\mathrm{OCH}_{3}$ to the $\mathrm{V}=\mathrm{O}$ bond associated with the same $\mathrm{V}$ atom. ${ }^{26-28}$ The decrease in production of $\mathrm{CH}_{2} \mathrm{O}$ above $425 \mathrm{~K}$ coincides with a rapid increase in the appearance of $\mathrm{CO}$ and $\mathrm{H}_{2} \mathrm{O}$, suggesting that the latter products are formed by the decomposition and partial combustion of $\mathrm{CH}_{2} \mathrm{O}$. The mechanisms for these processes were not studied as a part of the present investigation; however, Raskó et al. ${ }^{29}$ have shown that formaldehyde will decompose under similar conditions. The coincidence of $\mathrm{CO}$ formation with the appearance of an intense formate band at $1575 \mathrm{~cm}^{-1}$ (see Figure 11) supports the hypothesis that formate species formed by the adsorption of $\mathrm{CH}_{2} \mathrm{O}$ are intermediates along the path to $\mathrm{CO}$ and $\mathrm{H}_{2}$.

With further increase in temperature, a small DME peak appears along with large peaks for $\mathrm{CO}, \mathrm{CH}_{4}$, and $\mathrm{H}_{2}$. The DME peak appears at the same temperature on $\mathrm{V} / \mathrm{TiO}_{2}$ during TPD as on $\mathrm{TiO}_{2}$, suggesting that this product is formed exclusively by the condensation of two $\mathrm{Ti}-\mathrm{OCH}_{3}$ groups. The reason for the observed decrease in DME formation is due to both a decrease in the amount of $\mathrm{Ti}-\mathrm{OCH}_{3}$ species present on the surface and a rapid decomposition and combustion of $\mathrm{Ti}-\mathrm{OCH}_{3}$ species in the presence of supported vanadate groups. The temperature at which $\mathrm{CH}_{4}$ is formed on $\mathrm{V} / \mathrm{TiO}_{2}$ is significantly lower than that seen for $\mathrm{TiO}_{2}$ alone, $575 \mathrm{~K}$ versus $650 \mathrm{~K}$. While the exact origin of $\mathrm{CH}_{4}$ in this case is not clear, a possible source is the decomposition of DME or the reaction of $\mathrm{Ti}-\mathrm{OCH}_{3}$ groups with $\mathrm{H}$ atoms released during the decomposition of DME. It is also notable that the total amount of $\mathrm{H}_{2} \mathrm{O}$ produced during the TPD of adsorbed methanol on $\mathrm{V} / \mathrm{TiO}_{2}$ is nearly twice that observed in the TPD spectrum for methanol adsorbed on $\mathrm{TiO}_{2}$. Consistent with this, Table 2 shows that the total amount of $\mathrm{O}$ atoms present in the products of TPO from $\mathrm{V} / \mathrm{TiO}_{2}$ is 1.8 times that contained in the methanol initially adsorbed. Because, as noted above, $\mathrm{TiO}_{2}$ is a poor source of $\mathrm{O}$, this observation suggests that $1.6 \mathrm{O} / \mathrm{nm}^{2}$ are taken from the supported vanadate species, of which there are $2.0 \mathrm{~V} / \mathrm{nm}^{2}$. Therefore, during the TPD of methanol adsorbed on $\mathrm{V} / \mathrm{TiO}_{2}, 80 \%$ of the $\mathrm{V}^{5+}$ in isolated vanadate species is reduced to $\mathrm{V}^{3+}$.

Infrared spectra recorded during the TPO of methanol adsorbed on $\mathrm{V} / \mathrm{TiO}_{2}$ are presented in Figure 13, and the composition of the gas phase is presented in Figure 14. Figure 13 shows that the loss of both $\mathrm{Ti}-\mathrm{OCH}_{3}$ and $\mathrm{V}-\mathrm{OCH}_{3}$ surface species occurs at much lower temperatures than is seen during TPD (compare with Figure 11) and that nearly all of the surface methoxide species are removed by $523 \mathrm{~K}$. There are also two new features at 1350 and $1555 \mathrm{~cm}^{-1}$ formed at temperatures between 423 and $573 \mathrm{~K}$, which are attributed to surface formate species. The feature at $1640 \mathrm{~cm}^{-1}$, which is only observed at $473 \mathrm{~K}$, is attributed to gas-phase $\mathrm{H}_{2} \mathrm{O}$, because this is the temperature where the $\mathrm{H}_{2} \mathrm{O}$ desorption is maximized during TPO. The TPO spectrum of $\mathrm{CH}_{3} \mathrm{OH}$ adsorbed on $\mathrm{V} / \mathrm{TiO}_{2}$, shown in Figure 14, is much simpler than the corresponding TPD spectrum (Figure 12). As in the TPD spectrum, desorption of $\mathrm{CH}_{3} \mathrm{OH}$ begins at $350 \mathrm{~K}$. This process is accompanied by the immediate onset of $\mathrm{CH}_{2} \mathrm{O}$ and $\mathrm{H}_{2} \mathrm{O}$ formation at virtually equivalent rates. Above $425 \mathrm{~K}$ the rate of $\mathrm{CH}_{2} \mathrm{O}$ formation reaches a maximum as $\mathrm{CO}$ now forms, and the rate of $\mathrm{H}_{2} \mathrm{O}$ formation accelerates. Table 2 shows that the total amount of $\mathrm{H}_{2} \mathrm{O}$ formed, $2.32 \mathrm{H}_{2} \mathrm{O} / \mathrm{nm}^{2}$, agrees perfectly with that expected
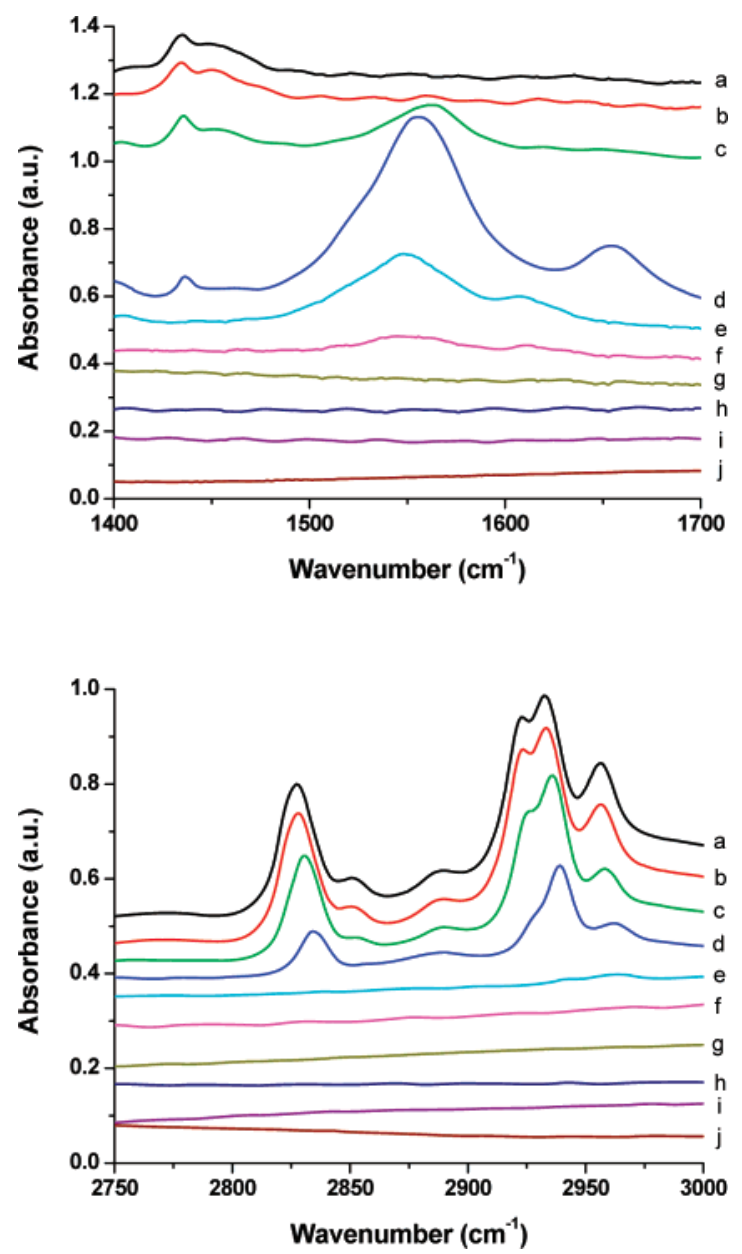

Figure 13. Low and high wavenumber infrared spectra of $\mathrm{V} / \mathrm{TiO}_{2}$ taken during TPO of adsorbed methanol. Flow rate of $5 \% \mathrm{O}_{2} / \mathrm{He}: 30 \mathrm{~cm}^{3}$ $\min ^{-1}$. (a) $323 \mathrm{~K}$, (b) $373 \mathrm{~K}$, (c) $423 \mathrm{~K}$, (d) $473 \mathrm{~K}$, (e) $523 \mathrm{~K}$, (f) 573 K, (g) $623 \mathrm{~K}$, (h) $673 \mathrm{~K}$, (i) $723 \mathrm{~K}$, (j) $773 \mathrm{~K}$.

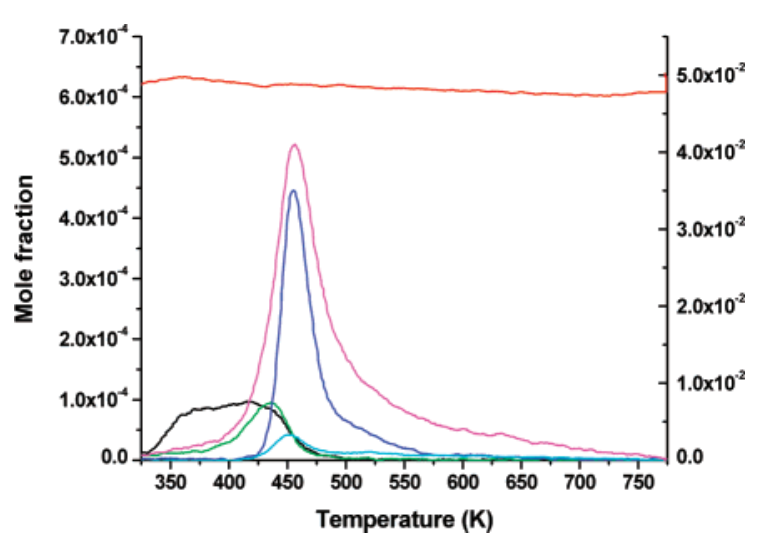

Figure 14. Gas-phase concentrations observed during TPO of methanol adsorbed on $\mathrm{V} / \mathrm{TiO}_{2}$. Flow rate of $5 \% \mathrm{O}_{2} / \mathrm{He}: 30 \mathrm{~cm}^{3} \mathrm{~min}^{-1}$. Left axis: methanol-black, formaldehyde-green, water-pink, carbon monoxideblue, carbon dioxide-light blue. Right axis: oxygen-red.

from the production of $\mathrm{CH}_{2} \mathrm{O}$ and $\mathrm{CO}$, assuming that the later product comes from the decomposition of $\mathrm{CH}_{2} \mathrm{O}$ to $\mathrm{CO}$ and $\mathrm{H}_{2}$ followed by the immediate combustion of $\mathrm{H}_{2}$ to $\mathrm{H}_{2} \mathrm{O}$. The infrared spectra taken during TPO presented in Figure 13 show that the methoxide species present as $\mathrm{Ti}-\mathrm{OCH}_{3}$ react much more rapidly than those present as $\mathrm{V}-\mathrm{OCH}_{3}$. This suggests that most of the $\mathrm{CH}_{3} \mathrm{OH}$ desorbed in the initial part of the TPO spectrum is due to the reaction of $\mathrm{Ti}-\mathrm{OCH}_{3} / \mathrm{Ti}-\mathrm{OH}$ pairs to form $\mathrm{CH}_{3} \mathrm{OH}$ and $\mathrm{Ti}-\mathrm{O}-\mathrm{Ti}$ bonds. 


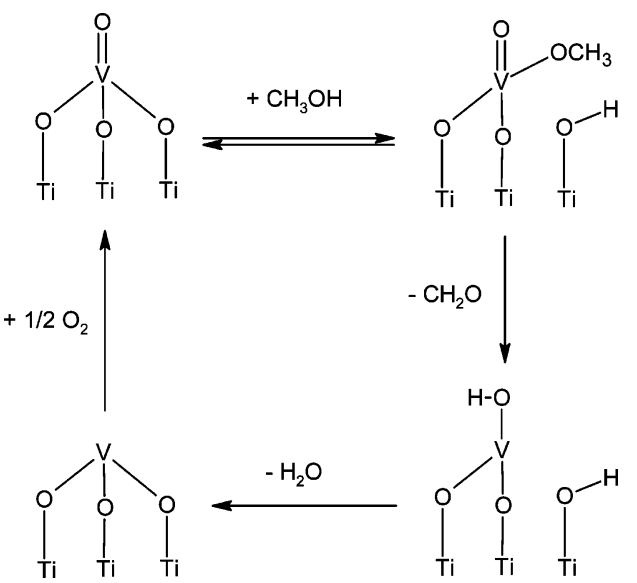

Figure 15. Scheme of catalytic cycle at isolated $\mathrm{VO}_{4}$ species on $\mathrm{TiO}_{2}$ showing the conversion of methanol to formaldehyde and water. Reoxidation of the catalyst does not occur during TPD.

A possible mechanism for the formation of $\mathrm{CH}_{2} \mathrm{O}$ during the TPO of $\mathrm{CH}_{3} \mathrm{OH}$ adsorbed on $\mathrm{V} / \mathrm{TiO}_{2}$ is shown in Figure 15. $\mathrm{V}-\mathrm{OCH}_{3}$ groups are shown as the source of $\mathrm{CH}_{2} \mathrm{O}$ and $\mathrm{H}_{2} \mathrm{O}$. $\mathrm{CO}, \mathrm{CO}_{2}$, and additional $\mathrm{H}_{2} \mathrm{O}$ are then formed in secondary processes involving the decomposition and oxidation of $\mathrm{CH}_{2} \mathrm{O}$. The infrared spectra presented in Figure 13 are consistent with the idea that $\mathrm{CO}$ and $\mathrm{CO}_{2}$ result from the secondary reaction of $\mathrm{CH}_{2} \mathrm{O}$. As seen in this figure, a strong formate band appears at $1555 \mathrm{~cm}^{-1}$, reaches a maximum, and then disappears over the temperature range of $423-573 \mathrm{~K}$. This is the same temperature range over which the peaks for $\mathrm{CO}, \mathrm{CO}_{2}$, and $\mathrm{H}_{2} \mathrm{O}$ are observed in the TPO spectrum (Figure 14). A further point of interest is that in contrast to what is seen during the TPD of $\mathrm{CH}_{3} \mathrm{OH}$ adsorbed on $\mathrm{V} / \mathrm{TiO}_{2}$, no product peaks are observed above 550 $\mathrm{K}$ during TPO of adsorbed $\mathrm{CH}_{3} \mathrm{OH}$. This is very likely a consequence of the rapid reoxidation of $\mathrm{V}^{3+}$ to $\mathrm{V}^{5+}$ occurring at lower temperatures in the presence of gas-phase oxygen, enabling the complete conversion of $\mathrm{V}-\mathrm{OCH}_{3}$ groups to $\mathrm{CH}_{2} \mathrm{O}$, as well as increasing the rate of subsequent decomposition of $\mathrm{CH}_{2} \mathrm{O}$ to $\mathrm{CO}$ and $\mathrm{H}_{2} \mathrm{O}$. The scheme shown in Figure 15 assumes that all of the $\mathrm{CH}_{2} \mathrm{O}, \mathrm{CO}$, and $\mathrm{CO}_{2}$ observed during the TPO of methanol adsorbed on $\mathrm{V} / \mathrm{TiO}_{2}$ originate from $\mathrm{V}-\mathrm{OCH}_{3}$ groups. This would suggest that $1.50 \mathrm{C}$ atoms $/ \mathrm{nm}^{2}$ are present as $\mathrm{V}-\mathrm{OCH}_{3}$ groups at the start of TPO. However, this figure is larger than the value of $1.0 \mathrm{C} / \mathrm{nm}^{2}$ determined on the basis of the total uptake of $\mathrm{CH}_{3} \mathrm{OH}$ as $\mathrm{V}-\mathrm{OCH}_{3}$ groups (see above), which leads to the suggestion that during TPO methoxide groups attached to $\mathrm{Ti}$ atoms migrate across the support and are transferred to the vanadate groups via reverse spillover. This interpretation would also explain why the bands for $\mathrm{Ti}-\mathrm{OCH}_{3}$ species disappear from the infrared spectrum at lower temperatures for $\mathrm{V} / \mathrm{TiO}_{2}$ than for $\mathrm{TiO}_{2}$ during TPO of adsorbed $\mathrm{CH}_{3} \mathrm{OH}$

The positions of the formate band on $\mathrm{V} / \mathrm{TiO}_{2}$ observed during the TPD and TPO experiments are different. During TPD, the band is at $1575 \mathrm{~cm}^{-1}$, but during TPO the band shifts to 1555 $\mathrm{cm}^{-1}$. A possible reason for these differences is shown in Figure 16. During TPD, the formates are created by the reaction of $\mathrm{CH}_{2} \mathrm{O}$ with $\mathrm{V}^{3+}$ centers produced during the formation of $\mathrm{CH}_{2} \mathrm{O}$, followed by the transfer of a hydrogen atom; however, in the presence of gas-phase oxygen, the vanadium is rapidly reoxidized, and the $\mathrm{CH}_{2} \mathrm{O}$ would, therefore, be more likely to interact with $\mathrm{V}^{5+}$ centers. The formate species at the reoxidized vanadium centers are expected to be more active to further oxidization, which would also explain both the large increase in the amount of $\mathrm{CO}$ and $\mathrm{CO}_{2}$ formed during the TPO experiment and the shift of all oxidation products to lower temperatures. Formates on reduced vanadium centers during the TPD experiment on $\mathrm{V} / \mathrm{TiO}_{2}$ are not as active toward decomposition to form $\mathrm{CO}$ and $\mathrm{H}_{2} \mathrm{O}$.

The results of TPRx on $\mathrm{V} / \mathrm{TiO}_{2}$ are illustrated in Figures 17and 18. The infrared spectra recorded at reaction temperatures between 373 and $773 \mathrm{~K}$, shown in Figure 17, are very similar to those shown in Figure 13 for the TPO of adsorbed methanol taken over the same temperature range. Here again, the Ti$\mathrm{OCH}_{3}$ species are observed to disappear first. It is also noted that the formation of formate species coincides with the onset of $\mathrm{CO}$ formation. However, a new feature is observed at 1612 $\mathrm{cm}^{-1}$ between 623 and $723 \mathrm{~K}$, which is due to adsorbed $\mathrm{H}_{2} \mathrm{O}$. The formation of $\mathrm{CH}_{2} \mathrm{O}$ and $\mathrm{H}_{2} \mathrm{O}$ at equivalent rates was also observed during the TPRx of methanol over anatase. Below 475 $\mathrm{K}$ these are the only products formed, but above $475 \mathrm{~K}$, the rates of $\mathrm{CO}$ and $\mathrm{H}_{2} \mathrm{O}$ formation increase rapidly, as the rate of $\mathrm{CH}_{2} \mathrm{O}$ formation passes through a maximum. These observations are consistent with the reaction sequence presented in Figure 15. Also notable is the absence of any evidence for the oxidation of methanol over $\mathrm{TiO}_{2}$, as can be concluded by comparison of the data presented in Figures 9 and 18.

A point of considerable interest is that $\mathrm{Ti}-\mathrm{OCH}_{3}$ species appear to be much more reactive on $\mathrm{V} / \mathrm{TiO}_{2}$ than on $\mathrm{TiO}_{2}$. This is clearly evident, for example, from a comparison of the infrared spectra observed during TPRx of $\mathrm{CH}_{3} \mathrm{OH} / \mathrm{O}_{2}$ over $\mathrm{TiO}_{2}$ and $\mathrm{V} / \mathrm{TiO}_{2}$. During $\mathrm{TPRx}$ on $\mathrm{TiO}_{2}$, some $\mathrm{Ti}-\mathrm{OCH}_{3}$ species remain on the surface of the solid at $723 \mathrm{~K}$. By contrast, the same species are removed completely by $523 \mathrm{~K}$ during the TPRx of $\mathrm{CH}_{3} \mathrm{OH} / \mathrm{O}_{2}$ on $\mathrm{V} / \mathrm{TiO}_{2}$. A definitive explanation for this phenomenon cannot be developed on the basis of the data obtained in this study. One possibility is that the methoxide groups associated with $\mathrm{Ti}$ cations diffuse along the catalyst surface until they come into proximity with supported vanadate groups leading to the formation of $\mathrm{CH}_{2} \mathrm{O}$. This would lead to a reverse spillover of the methoxide groups from $\mathrm{Ti}$ to $\mathrm{V}$, similar to the results proposed by Seman and Oyama ${ }^{30}$ for $\mathrm{Mo} / \mathrm{SiO}_{2}$ and $\mathrm{Chen}$ and Falconer ${ }^{31}$ for $\mathrm{Ni} / \mathrm{Al}_{2} \mathrm{O}_{3}$. Another possibility is that, in the absence of vanadate species, the formation of anionic vacancies in $\mathrm{TiO}_{2}$ leads to a stabilization of the remaining methoxide groups in the form of structures in which the $\mathrm{O}$ atom of the methoxide bridges between two Ti cations. Such bridging methoxide groups would then be stable until they began to condense and form DME or undergo other reactions leading to $\mathrm{CH}_{4}$ and $\mathrm{H}_{2}$. In the presence of $\mathrm{O}_{2}$ such bridging methoxide groups would oxidize to form $\mathrm{CO}$ and $\mathrm{H}_{2} \mathrm{O}$. When vanadate species are present on the surface of $\mathrm{TiO}_{2}$, these species can undergo reduction to form $\mathrm{V}(-\mathrm{OTi} \equiv)_{3}$ species. A recent theoretical study has shown that the latter species can readily adsorb $\mathrm{O}_{2} \cdot{ }^{27}$ Migration of one of the $\mathrm{O}$ atoms of the newly formed peroxo group into $\mathrm{TiO}_{2}$ could then result in the removal of an oxygen anion defect in the support. Under this hypothesis, the removal of anionic defects in $\mathrm{TiO}_{2}$ would restore the reactivity of $\mathrm{Ti}-\mathrm{OCH}_{3}$ groups on the surface of the support so that they could desorb as methanol by condensation with $\mathrm{Ti}-$ $\mathrm{OH}$ groups. This interpretation would require, though, for defects to have a long-range effect, since work by Henderson and coworkers has shown that $8 \%$ of the surface of $\mathrm{TiO}_{2}$ had defects in the absence of $\mathrm{O}_{2}$ and $2 \%$ in the presence of $\mathrm{O}_{2} \cdot{ }^{10}$ Attempts to develop a clearer understanding of the role of vanadate species on the reactivity of $\mathrm{Ti}-\mathrm{OCH}_{3}$ species are currently in progress.

The TPRx data presented in Figure 18 were analyzed to determine the apparent first-order rate coefficient for formaldehyde formation. To this end, the natural logarithm of the rate 

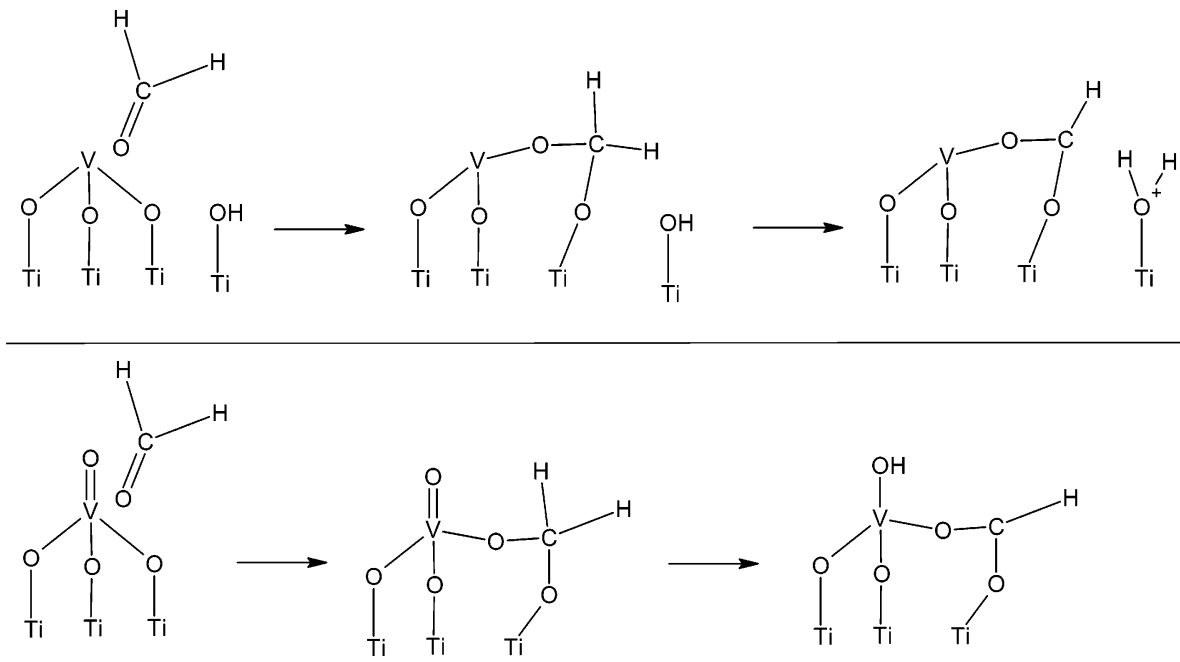

Figure 16. Possible reaction pathways to explain the presence of formates on the surface. The first pathway is for $\mathrm{TPD}$ on $\mathrm{V} / \mathrm{TiO} \mathrm{O}_{2}$, and the second pathway is for TPO on $\mathrm{V} / \mathrm{TiO}_{2}$.
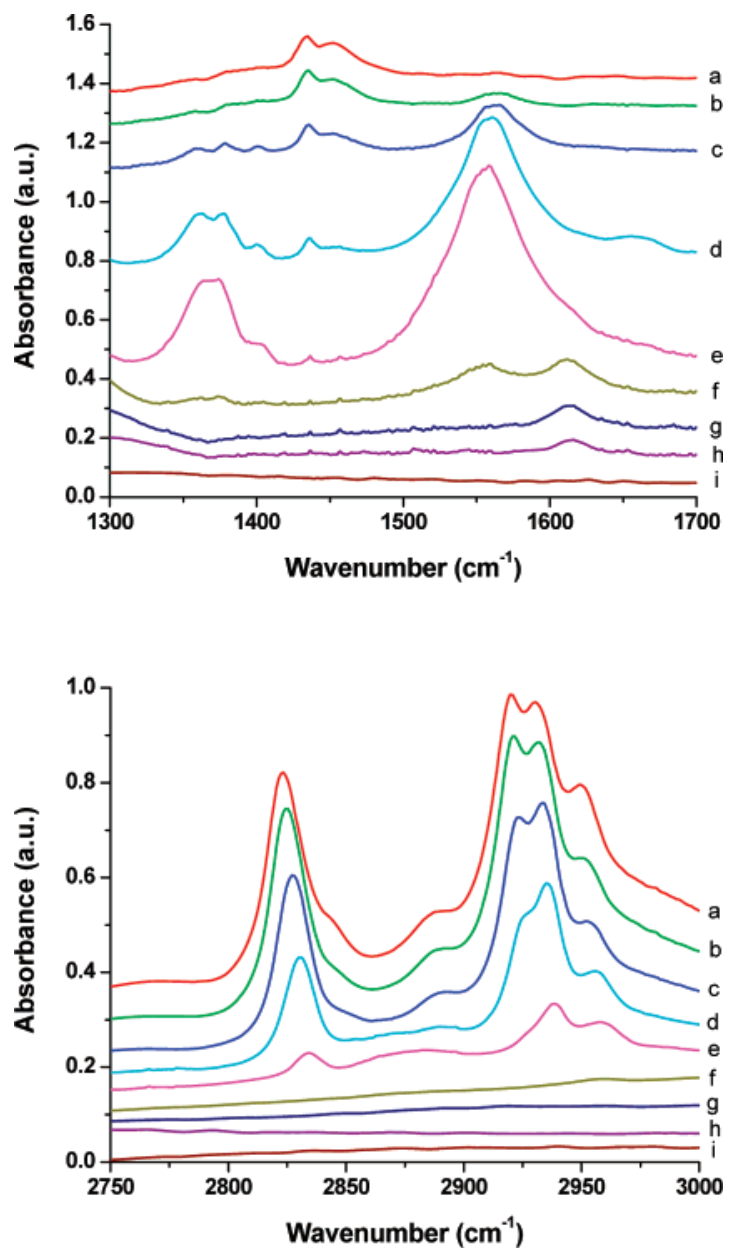

Figure 17. Low and high wavenumber infrared spectra of $\mathrm{V} / \mathrm{TiO}_{2}$ taken during TPRx in $5 \% \mathrm{MeOH} / 12 \% \mathrm{O}_{2} / \mathrm{He}$ flowing at $30 \mathrm{~cm}^{3} \mathrm{~min}^{-1}$. (a) $373 \mathrm{~K}$, (b) $423 \mathrm{~K}$, (c) $473 \mathrm{~K}$, (d) $523 \mathrm{~K}$, (e) $573 \mathrm{~K}$, (f) $623 \mathrm{~K}$, (g) 673 K, (h) $723 \mathrm{~K}$, (i) $773 \mathrm{~K}$

of formaldehyde formation was plotted versus inverse temperature. The apparent activation energy calculated from the slope of the line is $16 \mathrm{kcal} / \mathrm{mol}$, and the apparent preexponential factor is $5.3 \times 10^{6} \mathrm{~atm}^{-1} \mathrm{~s}^{-1}$. The values of these parameters can be compared with those obtained by similar means for methanol oxidation to formaldehyde occurring on isolated vanadate species supported on silica. In that case, the apparent activation
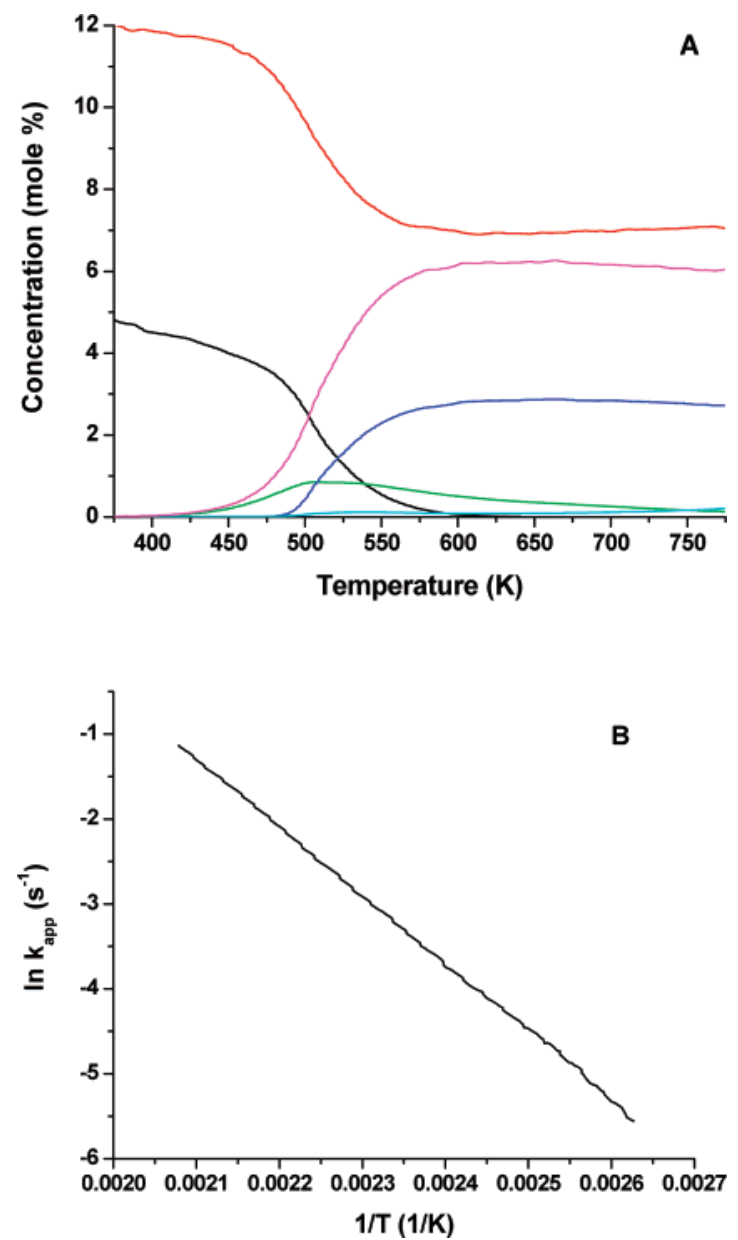

Figure 18. (A) Gas-phase concentrations observed during TPRx of $\mathrm{V} / \mathrm{TiO}_{2}$ in $5 \% \mathrm{MeOH} / 12 \% \mathrm{O}_{2} / \mathrm{He}$ flowing at $30 \mathrm{~cm}^{3} \mathrm{~min}^{-1}$. Methanolblack, oxygen-red, formaldehyde-green, water-pink, carbon monoxideblue, carbon dioxide-light blue. (B) An Arrhenius plot for the formaldehyde formation.

energy is $23 \mathrm{kcal} / \mathrm{mol}$ and the apparent preexponential factor is $2.3 \times 10^{7} \mathrm{~atm}^{-1} \mathrm{~s}^{-1} .{ }^{7}$ Based on these values, the specific activity of $\mathrm{V} / \mathrm{TiO}_{2}$ is $6.5 \times 10^{2}$ times higher than that of $\mathrm{V} / \mathrm{SiO}_{2}$ at 450 $\mathrm{K}$. This ratio of activities is on the same order of magnitude as that reported by Wachs and co-workers. ${ }^{1}$ What remains to be established, though, is whether the significantly higher activity of $\mathrm{V} / \mathrm{TiO}_{2}$ is due solely to the intrinsic effect of the support on 
the activity of the isolated vanadate units or, alternatively, to oxygen vacancies on the anatase surface or reverse spillover of methoxide species from the support. A theoretical effort is currently being undertaken to identify the role of each factor. It should be noted that an earlier theoretical study of methanol oxidation catalyzed by vanadate species supported on silica and titania showed the apparent activation energy to be $3 \mathrm{kcal} / \mathrm{mol}$ higher for isolated vanadates species supported on titania than on silica. ${ }^{26}$ This suggests that another mechanism, such as reverse spillover to the vanadate species, may be responsible for the increased activity of titania-supported vanadia.

\section{Conclusions}

The interactions of methanol with $\mathrm{TiO}_{2}$ (anatase) and $\mathrm{V} / \mathrm{TiO}_{2}$ $\left(2 \mathrm{~V} / \mathrm{nm}^{2}\right)$ were investigated by a number of techniques. Methanol adsorbs on $\mathrm{TiO}_{2}$ both molecularly and by addition across $\mathrm{Ti}-\mathrm{O}-\mathrm{Ti}$ bonds to form $\mathrm{Ti}-\mathrm{OCH}_{3} / \mathrm{Ti}-\mathrm{OH}$ pairs. Upon heating in the absence of $\mathrm{O}_{2}$, a portion of the $\mathrm{Ti}-\mathrm{OCH}_{3} / \mathrm{Ti}-$ $\mathrm{OH}$ pairs recombine to form $\mathrm{CH}_{3} \mathrm{OH}$, and $\mathrm{H}_{2} \mathrm{O}$ is formed by the recombination of pairs of $\mathrm{Ti}-\mathrm{OH}$ groups. At higher temperatures, $\mathrm{Ti}-\mathrm{OCH}_{3}$ groups react to form $\mathrm{DME}, \mathrm{CH}_{4}, \mathrm{CO}$, and $\mathrm{H}_{2}$. The decomposition and oxidation of $\mathrm{Ti}-\mathrm{OCH}_{3}$ groups to form $\mathrm{CO}, \mathrm{CO}_{2}$, and $\mathrm{H}_{2} \mathrm{O}$ occur when heating is carried out in the presence of $\mathrm{O}_{2}$. Evidence for $\mathrm{V}-\mathrm{OCH}_{3} / \mathrm{Ti}-\mathrm{OH}$ pairs as well as $\mathrm{Ti}-\mathrm{OCH}_{3} / \mathrm{Ti}-\mathrm{OH}$ pairs is seen when methanol is adsorbed on $\mathrm{V} / \mathrm{TiO}_{2} \cdot \mathrm{CH}_{2} \mathrm{O}$ is produced at low temperatures during heating of methanol adsorbed onto $\mathrm{V} / \mathrm{TiO}_{2}$ both in the presence and in the absence of $\mathrm{O}_{2}$. This product appears to originate from $\mathrm{V}-\mathrm{OCH}_{3}$ groups formed either upon the adsorption of $\mathrm{CH}_{3} \mathrm{OH}$ or by reverse spillover from methoxide groups present on the titania support. At higher temperatures, $\mathrm{CH}_{2} \mathrm{O}$ adsorbs to form formate species, which then undergo decomposition to form $\mathrm{CO}$ and $\mathrm{H}_{2}$, and in the presence of $\mathrm{O}_{2}$ to form $\mathrm{CO}, \mathrm{CO}_{2}$, and $\mathrm{H}_{2} \mathrm{O}$. The activity of $\mathrm{V} / \mathrm{TiO}_{2}$ for the formation of $\mathrm{CH}_{2} \mathrm{O}$ at $450 \mathrm{~K}$ is nearly 3 orders of magnitude higher than that of $\mathrm{V} / \mathrm{SiO}_{2}$. Most of the higher activity of $\mathrm{V} / \mathrm{TiO}_{2}$ is associated with the lower apparent activation energy for this catalyst $(16 \mathrm{kcal} / \mathrm{mol})$ relative to that for $\mathrm{V} / \mathrm{SiO}_{2}(23 \mathrm{kcal} / \mathrm{mol})$.

Acknowledgment. This work was supported by the Director, Office of Energy Research, Office of Basic Energy Sciences, Chemical Science Division, of the U.S. Department of Energy under Contract No. DE-AC02-05CH11231. Portions of this research were carried out at the Stanford Synchrotron Radiation
Laboratory, a national user facility operated by Stanford University on behalf of the U.S. Department of Energy, Office of Basic Energy Sciences.

Supporting Information Available: Plots of the $-\mathrm{OH}$ stretching region. This material is available free of charge via the Internet at http://pubs.acs.org.

\section{References and Notes}

(1) Deo, G.; Wachs, I. E. J. Catal. 1994, 146, 323.

(2) Baltes, M.; Cassiers, K.; Van Der Voort, P.; Weckhuysen, B. M.; Schoonheydt, R. A.; Vansant, E. F. J. Catal. 2001, 197, 160.

(3) Lim, S.; Haller, G. L. Appl. Catal., A 1999, 188, 277.

(4) Olthof, B.; Khodakov, J.; Bell, A. T.; Iglesia, E. J. Phys. Chem. B 2000, 104, 1516.

(5) Burcham, L. J.; Deo, G.; Gao, X.; Wachs, I. E. Top. Catal. 2000 $11 / 12,85$

(6) Deo, G.; Turek, A. M.; Wachs, I. E. Appl. Catal., A 1992, 91, 27.

(7) Bronkema, J.; Bell, A. T. J. Phys. Chem. C 2007, 111, 420. 533.

(8) Kim, K. S.; Barteau, M. A.; Farneth, W. E. Langmuir 1988, 4,

(9) Kim, K. S.; Barteau, M. A. Surf. Sci. 1989, 223, 13.

(10) Henderson, M. A.; Otero-Tapia, S.; Castro, M. E. Faraday Discuss. 1999, 114, 313.

(11) Feng, T.; Vohs, J. M. J. Catal. 2002, 208, 301.

(12) Wang, Q.; Madix, R. J. Surf. Sci. 2001, 474, 213.

(13) Wachs, I. E.; Weckhuysen, B. M. Appl. Catal., A 1997, 157, 67.

(14) Jentoft, R. E.; Deutsch, S. E.; Gates, B. C. Rev. Sci. Instrum. 1996, $67,2111$.

(15) Newville, M. J. Synchrotron Radiat. 2001, 8, 322.

(16) Ravel, B.; Newville, M. J. Synchrotron Radiat. 2005, 12, 537.

(17) Ohsake, T.; Izumi, F.; Fujiki, Y. J. Raman Spectrosc. 1978, 7, 321

(18) Xie, S.; Iglesia, E.; Bell, A. T. Langmuir 2000, 16, 7162.

(19) Chiker, F.; Nogier, J. Ph.; Bonardet, J. L. Catal. Today 2003, 78

(20) Wong, J.; Lytle, F. W.; Messmer, R. P.; Maylotte, D. H. Phys. Rev. B 1984, 30, 5596.

(21) Rossi, P. F.; Busca, G. Colloids Surf. 1985, 16, 95.

(22) Araña, J.; Garriga i Cabo, C.; Doña-Rodriguez, J. M.; GonzálezDíaz, O.; Herrera-Melián, J. A.; Pérez-Peña, J. Appl. Surf. Sci. 2004, 239, 60

(23) $10.8 \mathrm{Ti} / \mathrm{nm}^{2}$ calculated on the basis of the Ti-Ti nearest neighbor distance on anatase.

(24) Hayden, B. E.; King, A.; Newton, M. A. J. Phys. Chem. B 1999 103, 203.

(25) Burcham, L. J.; Wachs, I. E. Catal. Today 1999, 49, 467.

(26) Khaliullin, R.; Bell, A. T. J. Phys. Chem. B 2002, 106, 7832.

(27) Goodrow, A.; Bell, A. T. J. Phys. Chem. C, in press.

(28) Döbler, J.; Pritzsche, M.; Sauer, J. J. Am. Chem. Soc. 2005, 127, 10861

(29) Raskó, J.; Kecskés, T.; Kiss, J. J. Catal. 2004, 226, 183.

(30) Seman, M.; Kondo, N.; Domen, K.; Oyama, S. T. Chem. Lett. 2002, 11,1082 .

(31) Chen, B.; Falconer, J. L. J. Catal. 1993, 144, 214. 